\title{
Physicochemical Analysis of the Particulate Matter Emitted from Road Vehicle Engines
}

\author{
Remigiusz Jasiński $^{1}\left(\mathbb{D}\right.$, Beata Strzemiecka $^{2}$, Iwona Koltsov ${ }^{3}\left(\mathbb{D}\right.$, Jan Mizeracki ${ }^{3}$ and Paula Kurzawska ${ }^{1, *(\mathbb{C})}$ \\ 1 Faculty of Civil and Transport Engineering, Poznan University of Technology, 60-965 Poznan, Poland; \\ remigiusz.jasinski@put.poznan.pl \\ 2 Institute of Chemical Technology and Engineering, Poznan University of Technology, 60-965 Poznan, Poland; \\ beata.strzemiecka@put.poznan.pl \\ 3 Laboratory of Nanostructures, Institute of High-Pressure Physics of the Polish Academy of Sciences, \\ 01-142 Warsaw, Poland; i.koltsov@labnano.pl (I.K.); j.mizeracki@labnano.pl (J.M.) \\ * Correspondence: paula.kurzawska@put.poznan.pl
}

Citation: Jasiński, R.; Strzemiecka, B.

Koltsov, I.; Mizeracki, J.;

Kurzawska, P. Physicochemical Analysis of the Particulate Matter Emitted from Road Vehicle Engines. Energies 2021, 14, 8556. https:// doi.org/10.3390/en14248556

Academic Editor: Islam Md

Rizwanul Fattah

Received: 9 November 2021

Accepted: 14 December 2021

Published: 18 December 202

Publisher's Note: MDPI stays neutral with regard to jurisdictional claims in published maps and institutional affiliations.

Copyright: (c) 2021 by the authors. Licensee MDPI, Basel, Switzerland This article is an open access article distributed under the terms and conditions of the Creative Commons Attribution (CC BY) license (https:// creativecommons.org/licenses/by/ $4.0 /)$
Abstract: Air pollution with particulate matter from transport sources is a serious problem in terms of air quality and its impact on human health. The article attempts to test the emitted particles from piston engines in terms of their physical properties and chemical composition. The research test objects were a diesel engine with Euro 5 emission class and a petrol engine, which was a part of the scooter drive system. The conducted research consisted in the analysis of the number, mass, and volume of particles, as well as chemical analysis, using the methods: Fourier Transform Infrared Spectroscopy (FTIR), Scanning Electron Microscope with Energy Dispersive Spectroscopy (SEM-EDS), and Evolved gas analysis (EGA). The diesel engine emitted particles in the range of 50-120 nm. With the increase in the engine load, the specific emission of particulate matter increased. In the case of a gasoline engine running without load, the emission of particles smaller than $30 \mathrm{~nm}$ was mainly observed. Increasing load of the gasoline engine resulted in an increase in both the concentration of particles and their diameter (average diameter to $90 \mathrm{~nm}$ ). FTIR analysis showed higher black carbon content in the case of the sample taken from the diesel engine. In order to carry out a more detailed chemical analysis, the EGA and SEM methods were used. On their basis, the chemical composition of particles was presented, and a greater ability to agglomerate of a gasoline engine particles was found.

Keywords: combustion engines; particles emissions; chemical composition; SEM-EDS; FTIR

\section{Introduction}

Air quality has improved significantly in European cities over the past 20 years. The emission of sulfur oxides was mainly reduced: $\sim 80 \%$, nitrogen oxides: $\sim 46 \%$, non-methane volatile organic compounds: $\sim 44 \%$, particles with a diameter lower than $2.5 \mu \mathrm{m}$ and $10 \mu \mathrm{m}$ : $30 \%$ [1]. Nevertheless, European society is exposed to air pollution by $\mathrm{PM}_{2.5}$ and $\mathrm{O}_{3}$ at levels significantly exceeding the WHO limit values for the protection of human health [1]. This is related to premature mortality [2], estimated at 4.5 million deaths worldwide and approximately 0.5 million in Europe annually [3]. WHO, on their official website, states that $91 \%$ of people live in the area where air quality levels exceed WHO limits [4]. WHO, in Reference [5], says that the level of PM2.5 does not have a significant influence on human health in long-term time if it is $10 \mu \mathrm{g} / \mathrm{m}^{3}$ per year. Today, according to the official data presented by WHO, the level of PM2.5 in all European countries is $25 \mu \mathrm{g} / \mathrm{m}^{3}$ per year (except Switzerland, where it is $10 \mu \mathrm{g} / \mathrm{m}^{3}$ per year) [6].

Exposure to particles with diameter less than $2.5 \mu \mathrm{m}$ for several hours may result in cardiovascular-related mortality. Long-term exposure (e.g., several years) increases the risk of cardiovascular mortality, can cause pulmonary inflammation, and reduces life expectancy in the more vulnerable segments of the population by several months to several years $[7,8]$. Atmospheric pollution with particles emitted by combustion engines 
adversely affects human health. Particles smaller than $1 \mu \mathrm{m}$ in diameter can cause various diseases, especially heart and lung diseases, and related deaths. The worsening of disease is associated with the long-term effects of particles in the environment. They contribute to diseases, such as asthma and bronchitis. They are also one of the causes of heart arrhythmias and heart attacks. The most serious problems arise from the interaction of fine particles. People with heart and lung diseases, the elderly, and children have the lowest resistance to the negative effects of particulate matter. In impact analysis of air pollution on humans, in addition to common diseases, one should consider human cognitive abilities. Some scientists argue that air pollution negatively affects cognitive performance [9-11]. It was found that there are significant negative relationships between air pollutant exposure and cognitive function, especially PM2.5 exposure and long-term exposure. Additionally, it was found that the effect of PM on cognitive traits differs depending on the characteristics and attributes of the exposed person [12].

One of the main sources of particulate matter emissions in cities is road transport, especially vehicles with internal combustion engines (ICE), which are one of the main sources of particles emissions smaller than $1 \mu \mathrm{m}[13,14]$. Particles emissions emitted by compression ignition engines are from 6 to 10 times higher than emitted from spark ignition engines [15]. According to European Automobile Manufacturers Association (ACEA) Report for 2019, in European Union, 41.9\% of passenger cars, $91.2 \%$ of light commercial vehicles and $98.3 \%$ of medium and heavy commercial vehicles were diesel vehicles [16]. The average retirement age of diesel cars in 2012-2013 was 14.0 years, and it increased by almost $12 \%$ since 2006 . Lifetime mileage of diesel cars was approximately 208,000 km, based on data from 2012-2013 [17].

Particulate matter is one of the four main pollutants emitted by diesel engines, along with carbon monoxide (CO), nitrogen oxides (NOx), and hydrocarbons (HC). Particulate matter in internal combustion engines mainly arises as a result of incomplete combustion of hydrocarbons contained in the fuel and also from lube oil [15]. More than $90 \%$ of particles emitted by diesel engine are smaller than $1 \mu \mathrm{m}$, and most of the particles are between 15 and $40 \mathrm{~nm}$ in diameter $[15,18]$. Size distribution of particles emitted from diesel engines is bimodal, with mainly nucleation and accumulation mode [19]. There are many factors that influence the amount of particulate emissions from diesel engines. These are, among others: the age of the engine, the properties of the fuel supplying the engine, the level of maintenance of the vehicle and the driving style, environmental conditions, and the exhaust gas treatment technology used, but also the amount of oil scraped into the combustion chamber through the piston rings $[14,20]$. In order to reduce particulate emissions from internal combustion engines, particulate filters, such as the diesel particulate filter (DPF), are used. To function properly, filters used in diesel engines require periodic regeneration, which allows to remove accumulated solid particles. The efficiency of particle reduction for a properly functioning diesel particulate filter is about 95\% [21]. In 2009, Europe established a new EURO 5 standard, and, since then, DPF is mandatory in new diesel cars [22]. In 2011, a new EURO 5b standard came into force for light passenger and commercial vehicles, which set a limit for the number of particles of $6 \times 1011$ per $\mathrm{km}$, and was the first limitation of particles number [23]. The last established standard is EURO 6d, which has been in force since January 2021, but the limits for particles number and mass have not changed since EURO 5. As a diesel particulate filter is mandatory on new cars, many users of diesel cars remove the DPF to avoid the cleaning costs [22]. As a result of the removal of the DPF, the car no longer meets the applicable standards and is very harmful to the environment in terms of particulate matter. In many European countries, removal of DPFs is forbidden and punished with high fines $[22,24]$.

One of the solutions to reduce pollutant emissions in cities is to completely ban or limit the entry of vehicles that do not meet the relevant standards. Currently, there are Low Emission Zones (LEZs) in many countries, such as Italy, Spain, France, Germany, Belgium, and others, where the most polluting vehicles are regulated [25]. More and more countries are considering a permanent ban on diesel and gasoline cars to favor electric cars. Thirteen 
countries and several regions and cities announced ICE car bans until 2045 [26,27]. For this reason, development and researches of new technologies and trends in powertrains is inevitable. Currently, there are few configurations of electric powertrains: Plug-in Electric Vehicle (PEV), Plug-in Hybrid Vehicle (PHEV), Battery electric vehicle (BEV), and ExtendedRange Electric Vehicle (EREV) [28-30]. Thanks to an electric or hybrid drive system, that does not generate exhaust gases during use, it is possible to reduce greenhouse gases and other harmful exhaust gas compounds arising during combustion in a conventional engine. While electric cars still need electricity, which, in many countries, is produced from fossil fuels, reduction of harmful exhaust gas compounds emission is not so significant as it can be when electricity is produced from renewable energy sources [31]. However, another alternative for combustion engines is the Hydrogen Powered Vehicle (FCV), which use hydrogen fuel, that can be produced from zero-emission energy source [31]. Alternative powertrains can be considered as a relatively quick solution for reduction of harmful emission from road transport in countries with well-developed infrastructure for electric cars, while, in many countries, the main barriers will be the lack of charging infrastructure, insufficient or lack of information and promoting programs on the national level, and also high price for electric powertrains [30].

The other problem of PM is the influence of the chemical composition on the human health. There are many questions and problems that concern the analysis of the chemical composition of the PM:

1. Very complex composition of PM: many organic and inorganic compounds were found in PM up-to-date [32,33].

2. Very small amount of the compounds that are at the limit of the detection of the known nowadays techniques (e.g., benzo(a)pyrene present at PM2.5 was found equal to $15.4 \mathrm{ng} / \mathrm{m}^{3}$ per year in the Polish city of Katowice).

3. Many factors influence human health, and it is extremely hard (even impossible) to prove that the higher level of some particular compound is dangerous.

4. Because of the small amount of PM, the measurements are performed in the long term. Most often, the chemical composition of PM is assessed in the measurements at least collected in a day, mostly one month, or year. Thus, most often, the concrete hazardous compound present in PM can be assessed in the long term, and what is important for the risk for human is the time of exposure that is extremely (not possible) to assess as it will be very variable and dependent on many factors (e.g., weather, humidity).

Generally, WHO states that the largest sources of PM emission are solid fuel, households, and transport.

In this paper, the authors take into account the transport factor and assess the influence of the engine type, the conditions of its work on PM amount emission, and chemistry. Compared to other studies that have been carried out in the past few years, this article includes both particulate matter data analysis obtained from the particles analyzer, but also three different chemical analyzes: Fourier Transform Infrared Spectroscopy (FTIR), Scanning Electron Microscope with Energy Dispersive Spectroscopy (SEM-EDS), and Evolution Gas Analysis (EGA), while most research focuses on only one chemical analysis [34-36]. The authors of this paper verify the hypothesis of whether the type of engine and its work conditions influence/does not influence the chemistry of PM and this chemistry difference are/are not significant. Moreover, this paper gives a brief answer as to what technique can be adequate for quick and accurate PM chemistry studying.

\section{Materials and Methods}

\subsection{Test Engine, Fuels, Operating Schedule}

One of the tested engine was a compression ignition engine made by FCE Powertrains. The main parameters of this engine are presented in Table 1. The arrangement of the cylinders is in line with the Double Overhead Camshaft. The engine is fueled with diesel fuel and meets the EURO 5 standard. The engine has Common Rail direct injection 
system. The engine also has anelectronically controlled Exhaust Gas Recirculation valve, the operation of which is aimed at reducing the emission of harmful compounds in the exhaust gas. The EGR valve directs some of the exhaust gas from the exhaust system to the engine's intake system, thereby lowering the temperature in the combustion chamber and slowing down the combustion process. This allows the emission of nitrogen oxides to be reduced. The engine is also equipped with an oxidation catalytic converter and Diesel Particulate Filter.

Table 1. Engine's parameters.

\begin{tabular}{cc}
\hline Parameter & Value \\
\hline Engine type & Diesel engine \\
Capacity & $1.3 \mathrm{dm}^{3}$ \\
Power & $55 \mathrm{~kW}$ for $4000 \mathrm{rpm}$ \\
Torque & $190 \mathrm{Nm}$ for $1750-2500 \mathrm{rpm}$ \\
Number of cylinders & 4 \\
Number of valves & 16 \\
Piston stroke & $82 \mathrm{~mm}$ \\
Cylinder diameter & $69.6 \mathrm{~mm}$ \\
Compression ratio & $17.0: 1$ \\
\hline
\end{tabular}

The second tested engine was a spark ignition four-stroke engine with a capacity of $0.05 \mathrm{dm}^{3}$ used in motor scooter. The engine is fueled with unleaded gasoline 95 . Diesel engines were tested on an engine dynamometer test cell equipped with a brake AMX-210/100. The maximum power of the brake is $100 \mathrm{~kW}$, maximum torque is $240 \mathrm{Nm}$, and the rotation speed is $10,000 \mathrm{rpm}$. The tests were based on the engine load characteristics, which consist of assessing the change in basic engine parameters, depending on its load at constant crankshaft rotation speed. The tests were made for three rotation speeds: 1800,2100 , and $2400 \mathrm{rpm}$. For every rotation speed, at least seven engine loads were tested, from $15 \mathrm{Nm}$ to $135 \mathrm{Nm}$, in steps of $20 \mathrm{Nm}$. The exception is the test for $2100 \mathrm{rpm}$, when the regeneration of DPF has become apparent, and, for this rotation speed, the number of tested loads is 8 points.

In the case of the petrol engine, the research was conducted differently. Due to the fact that the engine was mounted on a scooter, it was necessary to use a chassis dynamometer for two-wheelers. Due to the above fact, it was only possible to carry out tests for the qualitative determination of whether the engine was under load or not.

\subsection{Apparatus and Procedures}

\subsubsection{PM Emissions}

Particulate matter concentration was measured with an Engine Exhaust Particle Sizer (EEPS 3090 analyzer, Shoreview, MN, USA). EEPS enables performance of the particle size distribution for discrete range of particle diameters, from $5.6 \mathrm{~nm}$ to $560 \mathrm{~nm}$. The exhaust gases are directed to the device via dilution system and temperature maintenance system. The pre-filter collects particles larger than $1 \mu \mathrm{m}$ in diameter that are outside the measuring range devices [37,38].

During the tests, the number concentration of particles in the exhaust gas was measured by EEPS, and the particulate matter sample was collected separately on the filter. The filter used in test was a Glass Fiber Filter $37 \mathrm{~mm}$. For the diesel engine, the EEPS probe was behind the diesel particulate filter, while the Glass Fiber Filter was in front of diesel particulate filter. The filter was placed in a separate pipe in which the pump drew in the exhaust gases from the exhaust system. For the petrol engine, the EEPS probe and the filter were in the exhaust of the motor scooter, and the filter also was between the exhaust system and the pump, which drew the exhaust gases in to pass them through the filter. 


\subsubsection{Fourier Transform Infrared Spectroscopy (FTIR)}

FTIR spectra of PM adsorbed on the filter were collected using Vertex 70, produced by Bruker, Billerica, MA, USA. The PM adsorbed on filter without any treatment were analyzed by use of the Attenuated total reflection (ATR) technique. The PIKE MIRacle ${ }^{\mathrm{TM}}$ accessory with diamond crystal was used. The measurements were performed at a resolution of $0.5 \mathrm{~cm}^{-1}$ in the wavenumber range $4000-400 \mathrm{~cm}^{-1}$.

\subsubsection{Scanning Electron Microscope with Energy Dispersive Spectroscopy (SEM-EDS)}

The morphology of the filters was investigated using a scanning electron microscope ULTRA PLUS (ZEISS, Oberkochen, Germany). The quantitative X-ray microanalysis of the materials was performed by the energy-dispersive spectrometry method using an X-ray spectrometer (Quantax 400, Bruker, Billerica, MA, USA).

\subsubsection{Evolved Gas Analysis (EGA)}

Evolved gas analysis combining differential scanning calorimetry (DSC) and thermogravimetry analysis (TG) (STA 449 F1 Jupiter apparatus from Netzsch GmbH, Selb, Germany) was conducted to determine the thermal decomposition of filters. Simultaneously, to the thermal decomposition of filters, the analysis of released gases took place using a mass spectrometer (QMS 403 Aeolos, from Netzsch GmbH, Selb, Germany). The measurements were carried out in synthetic air $\left(10 \mathrm{~cm}^{3} / \mathrm{min}\right)$ at heating rate of $10{ }^{\circ} \mathrm{C} / \mathrm{min}$ over a temperature range of $25-1200{ }^{\circ} \mathrm{C}$. The QMS was operated with an electron impact ionizer with an energy of $70 \mathrm{eV}$. The mass/charge $(\mathrm{m} / \mathrm{z})$ ratio was recorded in the range 2-200 amu during the measurements. For the experiment purpose, the biopsy tool was used to cut circular shape from the filter. In the test, 3 of those shapes were measured stacked on each other. The initial total sample weight taken for experiment was approximately $6 \mathrm{mg}$.

\section{Results}

\subsection{Particle Number Emission Indices}

The average $\mathrm{PM}$ number emission indices $\left(\mathrm{EI}_{\mathrm{N}}\right)$ and their associated error bars were calculated from EEPS data, as provided in Figure 1, for the different rotation speed. The average $\mathrm{EI}_{\mathrm{N}}$ for $1800 \mathrm{rpm}$ decreased from $1.9 \times 10^{15}$ to $9.3 \times 10^{13}$ particles per kilogram of fuel as the engine torque increased from 15 to $55 \mathrm{Nm}$. From a $55 \mathrm{Nm}$ average, $\mathrm{EI}_{\mathrm{N}}$ increased to $5.9 \times 10^{15}$ for $95 \mathrm{Nm}$, which was the highest $\mathrm{EI}_{\mathrm{N}}$ for $1800 \mathrm{rpm}$. The figure shows that, in comparison to the other rotation speeds, $1800 \mathrm{rpm}$ had the highest $\mathrm{EI}_{\mathrm{N}}$ values over the entire range of engine torque. For $2100 \mathrm{rpm}$ rotation speed, $\mathrm{EI}_{\mathrm{N}}$ values decreased from $8.9 \times 10^{13}$ to $6.8 \times 10^{13}$ particles per kilogram of fuel as the engine torque increased from 15 to $115 \mathrm{Nm}$. About torque equal to $144 \mathrm{Nm}$ regeneration of DPF (diesel particulate filter) has become. It caused an increase of $\mathrm{EI}_{\mathrm{N}}$ value from $6.9 \times 10^{13}$ to $4.9 \times 10^{14}$ particles per kilogram as the engine torque increased from 115 to $144 \mathrm{Nm}$. The average $\mathrm{EI}_{\mathrm{N}}$ for $2400 \mathrm{rpm}$ is after regeneration of DPF; thus, the average values of particles per kilogram of fuel are significantly lower than for 1800 and $2100 \mathrm{rpm}$. The values of $\mathrm{EI}_{\mathrm{N}}$ decreased from $1.9 \times 10^{13}$ to $1.0 \times 10^{13}$ as the engine torque increased from 15 to $135 \mathrm{Nm}$.

\subsection{PM Mass Emission Indices}

The PM mass emission indices $\left(\mathrm{EI}_{\mathrm{M}}\right)$, under various test conditions, were calculated from the EEPS measurements. Figure 2 shows the effect of rotation speed and engine torque on the $\mathrm{EI}_{\mathrm{M}}$. Similar to particle number emission indices, the mass emission indices in comparison to other rotation speeds are the highest for $1800 \mathrm{rpm}$ rotation speed in the entire range of engine torque. For $1800 \mathrm{rpm}$, the average $\mathrm{EI}_{\mathrm{M}}$ decreased from $1.14 \times 10^{3}$ to $3.0 \times 10$ milligrams per kilogram of fuel as the engine torque increased from 15 to $55 \mathrm{Nm}$. After that point, it increased to the highest value of $1.23 \times 10^{3}$ for $95 \mathrm{Nm}$. For $2100 \mathrm{rpm}$ rotation speed, the $\mathrm{EI}_{\mathrm{M}}$ decreased from $6.06 \times 10$ to 7.73 milligrams per kilogram of fuel as the engine torque increased from 15 to $75 \mathrm{Nm}$. From this point, it increased to $2.94 \times 10^{2}$ for $144 \mathrm{Nm}$, while the regeneration of DPF started. PM mass emission indices for rotation speed 
$2400 \mathrm{rpm}$ were the lowest from all tested rotation speeds because of the DPF regeneration. The average value of $\mathrm{EI}_{\mathrm{M}}$ decreased from 6.75 to 2.91 milligrams per kilogram of fuel as the engine torque increased from 15 to $135 \mathrm{Nm}$.

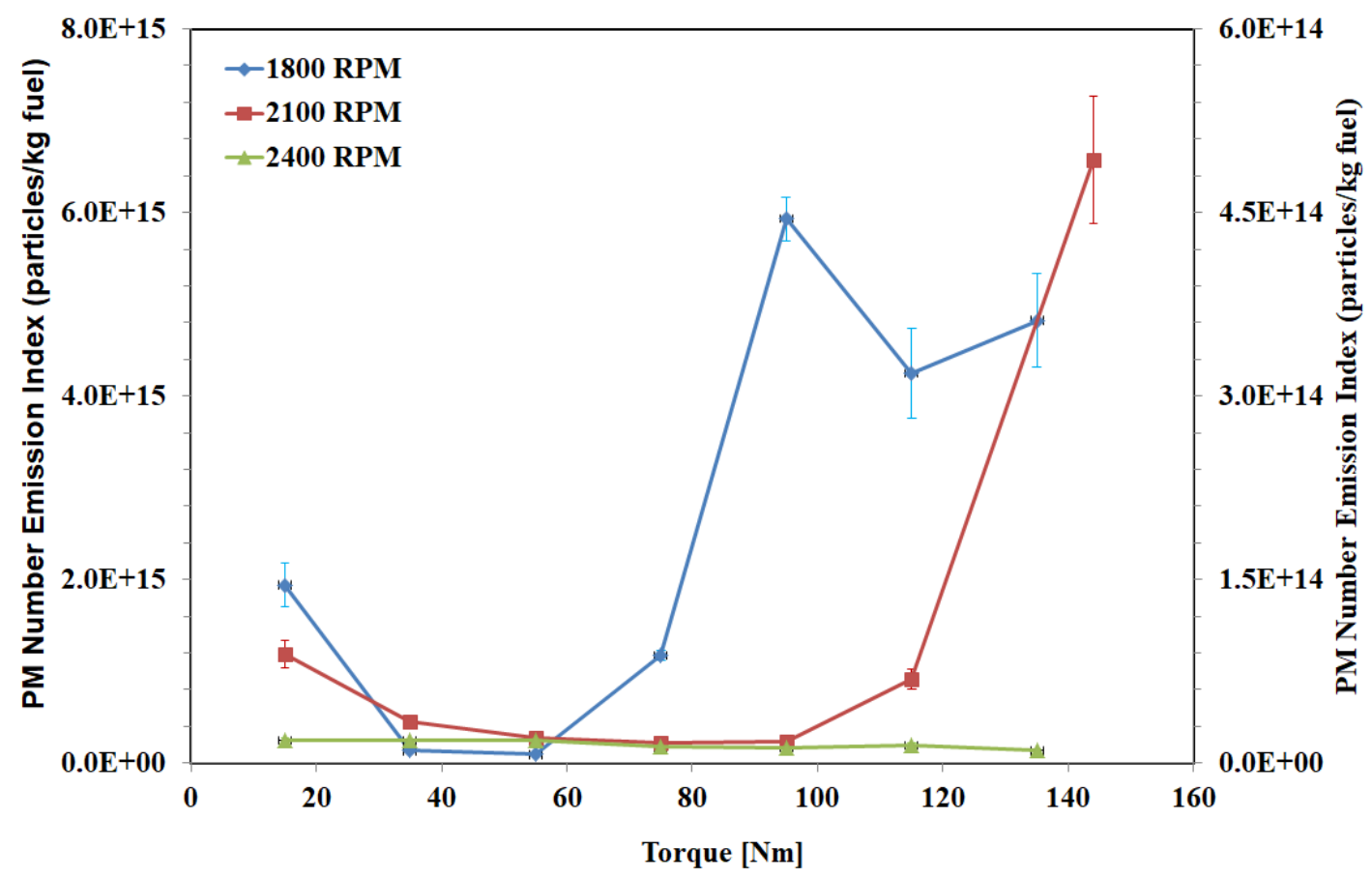

Figure 1. Particle number emissions index $\left(\mathrm{EI}_{\mathrm{N}}\right)$ versus torque. Error bars represent single standard deviation.

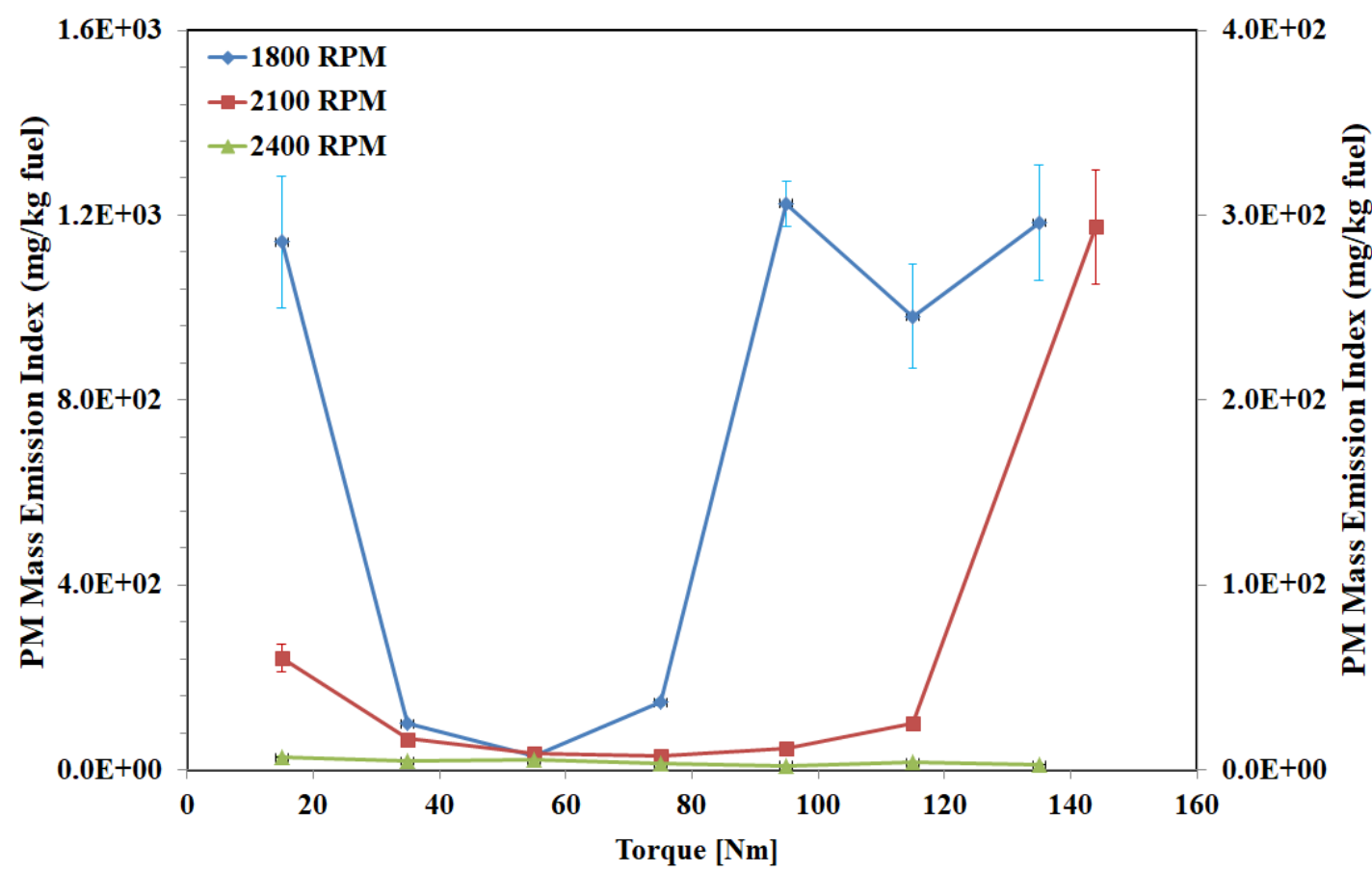

Figure 2. PM mass emission index $\left(\mathrm{EI}_{\mathrm{M}}\right)$ versus torque. Error bars represent one standard deviation.

\subsection{Particle Size Distribution}

The data recorded by the EEPS was averaged for the same engine torque and then converted to differential number-based $\left(\mathrm{dEI}_{\mathrm{N}} / \mathrm{d} \log \mathrm{D}_{\mathrm{p}}\right)$ and differential volume-based $\left(\mathrm{dEI}_{\mathrm{V}} / \mathrm{d} \log \mathrm{D}_{\mathrm{p}}\right)$ particle size distributions. Figure 3 represents example plots of $\mathrm{dEI}_{\mathrm{N}} / \mathrm{d} \log \mathrm{D}_{\mathrm{p}}$ 
and $\mathrm{dEI}_{\mathrm{V}} / \mathrm{d} \log \mathrm{D}_{\mathrm{p}}$ under different engine torques for rotation speed $1800 \mathrm{rpm}$ (Figure $\left.3 \mathrm{a}, \mathrm{b}\right)$, $2100 \mathrm{rpm}$ (Figure 3c,d), and for $2400 \mathrm{rpm}$ (Figure 3e,f).

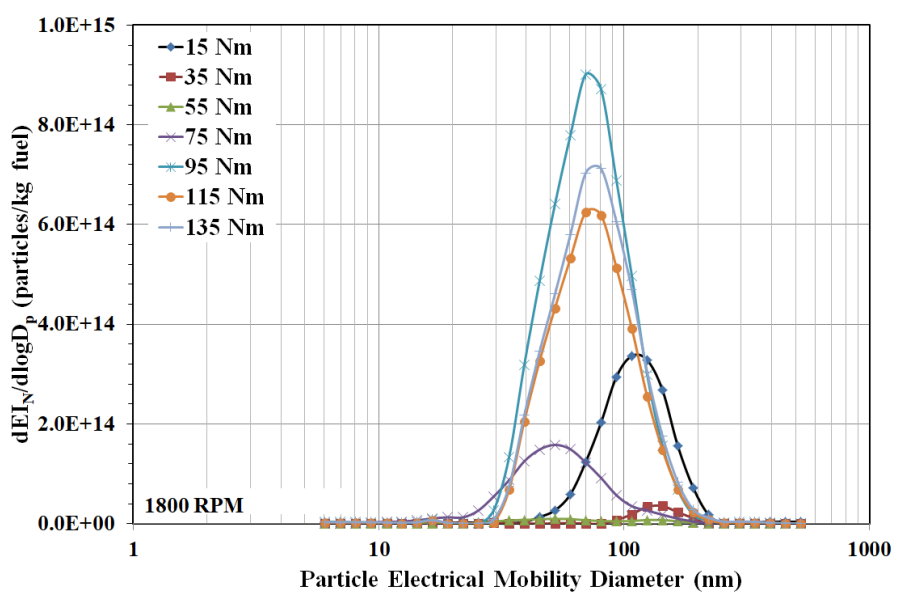

(a)

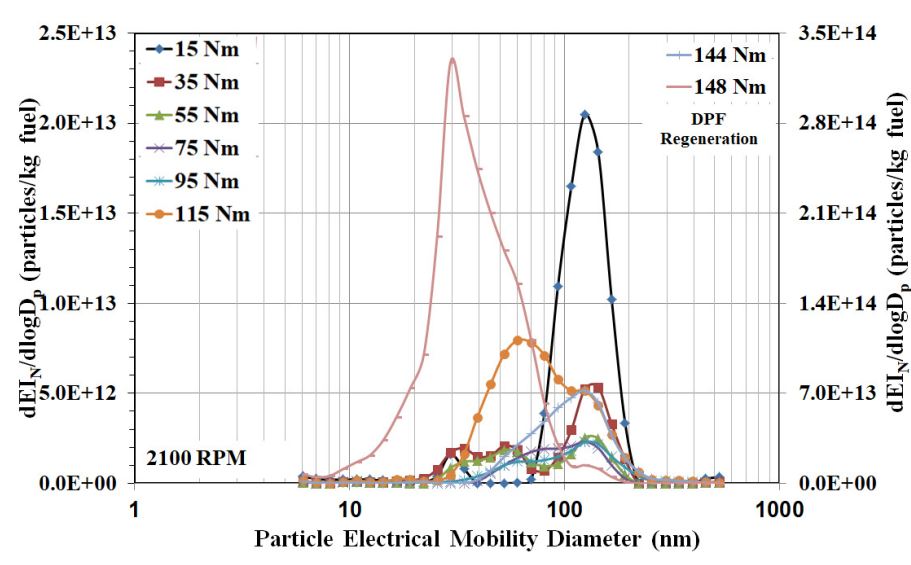

(c)

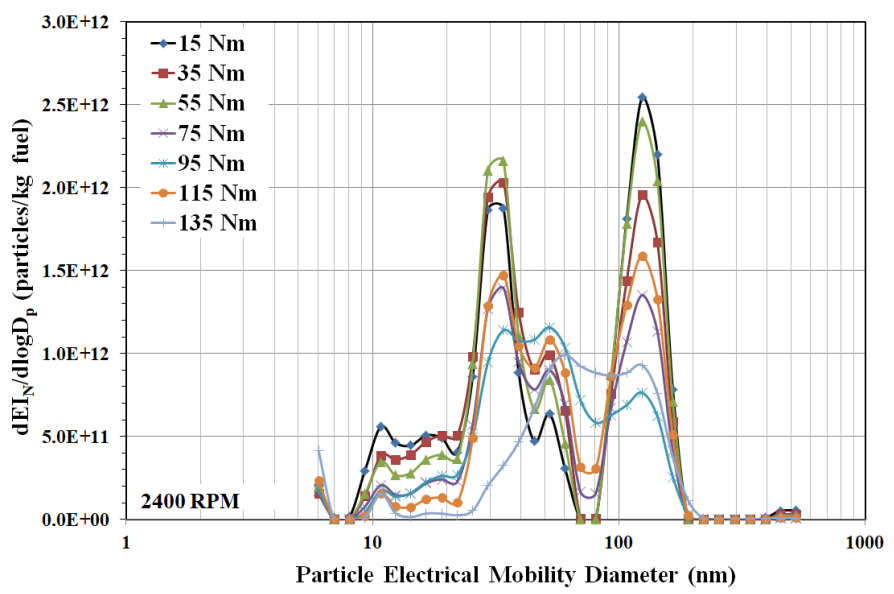

(e)

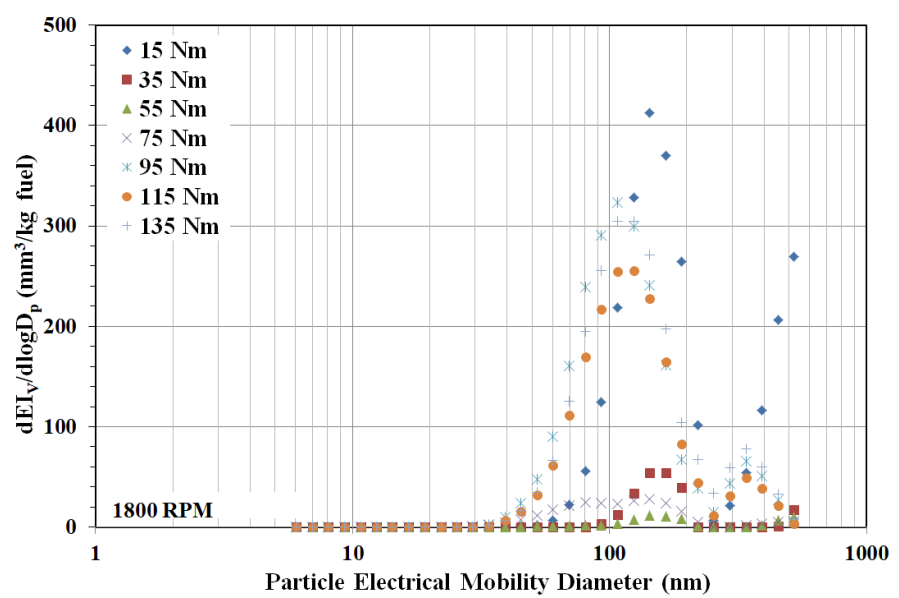

(b)

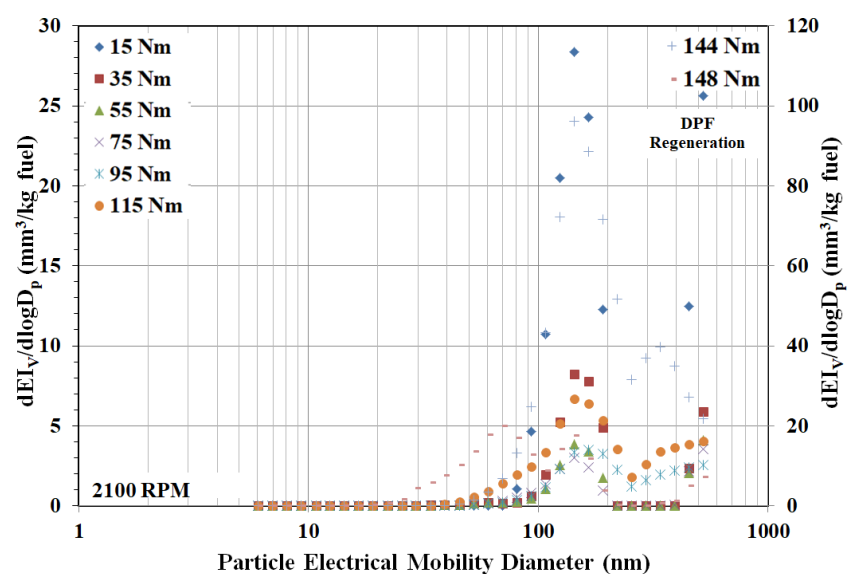

(d)

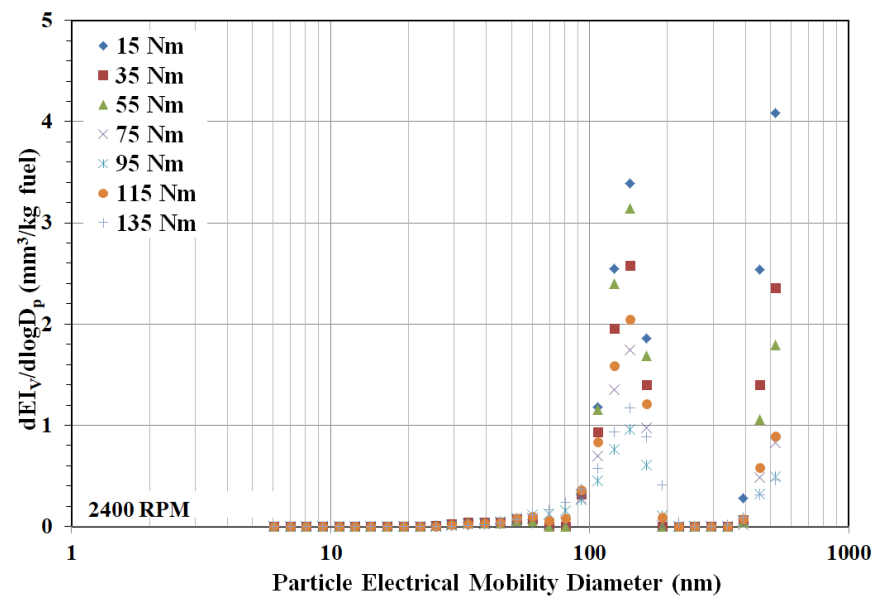

(f)

Figure 3. Differential particle number emission index $\left(\mathrm{EI}_{\mathrm{N}}\right)$ and differential particle volume emission index $\left(\mathrm{EI}_{\mathrm{V}}\right)$ PSDs: (a) $\mathrm{EI}_{\mathrm{N}}$ PSD for $1800 \mathrm{rpm}$; (b) EIV PSD for $1800 \mathrm{rpm}$; (c) $\mathrm{EI}_{\mathrm{N}}$ PSD for $2100 \mathrm{rpm}$; (d) $\mathrm{EI}_{\mathrm{V}}$ PSD for $2100 \mathrm{rpm}$; (e) EI $\mathrm{I}_{\mathrm{N}}$ PSD for $2400 \mathrm{rpm}$; (f) $\mathrm{EI}_{\mathrm{V}}$ PSD for $2400 \mathrm{rpm}$.

For rotation speed $1800 \mathrm{rpm}$, the particles formed in the accumulation mode dominate; thus, number-based PSD exhibited a single mode log-normal distribution. $\mathrm{EI}_{\mathrm{N}}$ and $\mathrm{EI}_{\mathrm{V}}$ 
was the highest for the last engine torques $(95,115$, and $135 \mathrm{Nm})$, but also for the first tested engine torque (15 Nm).

For $2100 \mathrm{rpm}$, mostly, the particles formed in the accumulation mode dominate. When the torque reached the point of $144 \mathrm{Nm}$, regeneration of DPF started; thus, for $148 \mathrm{Nm}$, the particles formed in nucleation mode dominate. Particle number emission index before regeneration of DPF is the highest for first tested torque $(15 \mathrm{Nm})$ and for the last tested engine torque before DPF regeneration $(115 \mathrm{Nm})$. After DPF regeneration started, the $\mathrm{EI}_{\mathrm{N}}$ is the highest for $148 \mathrm{Nm}$. Particle volume emission index before DPF regeneration is the highest for $15 \mathrm{Nm}$, and, for $144 \mathrm{Nm}$, when the regeneration happened.

PSD for 2400 rpm shows number emission index and volume emission index after regeneration of DPF. Number-based PSD exhibited a multimodal log-normal distribution. The particles formed in accumulation mode dominated, but there were also particles formed in nucleation mode. In addition, peak of accumulation mode was higher than nucleation mode. The highest $\mathrm{EI}_{\mathrm{N}}$ and $\mathrm{EI}_{\mathrm{V}}$ for almost all particles diameters was for the three first tested engine torques $(15,35$, and $55 \mathrm{Nm})$. The center of nucleation and accumulation peaks mostly decreased as engine torque increased. The median of change in average particle number and mass emission compared to $1800 \mathrm{rpm}$ rotational speed was, respectively, $99.0 \%$ and $99.4 \%$.

Figures 4-6 show the measurements results of particulate matter from the scooter in two phases: idling and under an average load on a chassis dynamometer. Figure 4 shows the dimensional distribution of particles. During idling, particles with a diameter of about $10 \mathrm{~nm}$ dominate, reaching the maximum value of $4.5 \times 10^{5}$. The engine load caused the dimensional distribution to shift to the right, towards larger particles. Thus, the dominant diameter is approximately $80 \mathrm{~nm}$. In addition to increasing the mean particle size, an increase in the concentration of the particles number was noted, reaching $1.3 \times 10^{6}$ for the diameter dominating in the distribution.

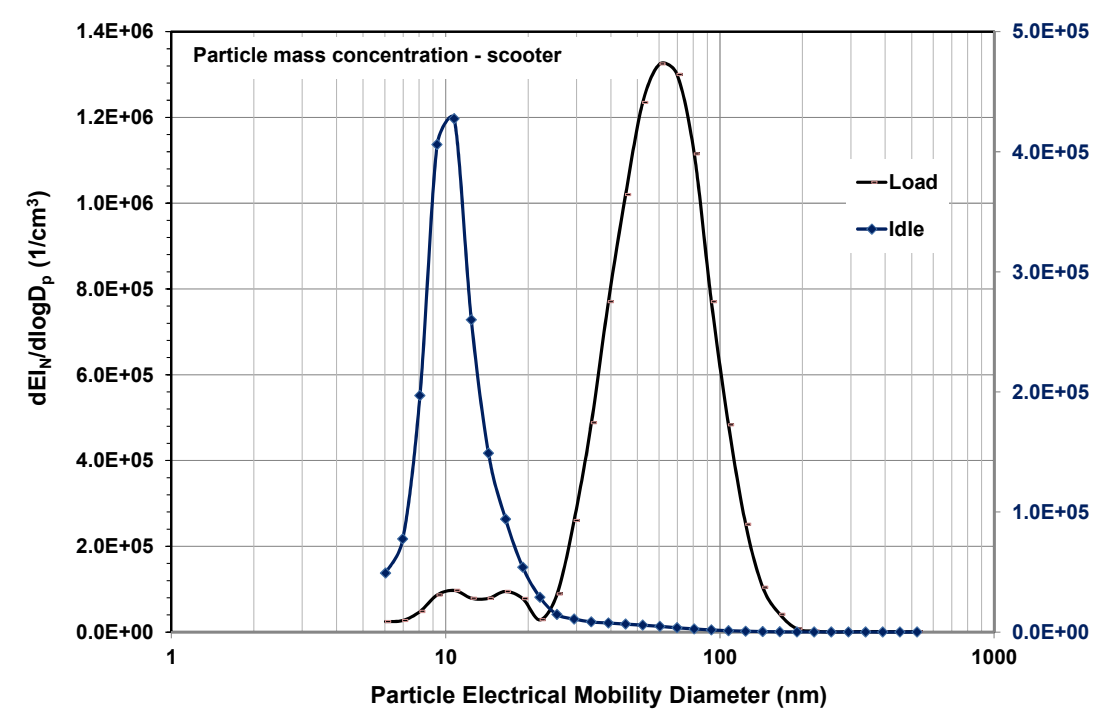

Figure 4. Particle number distribution obtained for scooter.

Figure 5 shows the mass distribution of particles. During idling, a trimodal mass distribution was noted. The largest share in the emitted mass particles is represented by particles with diameters greater than $50 \mathrm{~nm}$. A significant share is attributed to particles with a diameter of approximately $10 \mathrm{~nm}$, which results from their dominant number in the dimensional distribution. The engine load significantly changed the mass distribution to the unimodal one. It shows that over $95 \%$ of the emitted mass of particles were caused by particles with a diameter of 30-200 nm. Additionally, a significant increase in mass concentration was noted. 


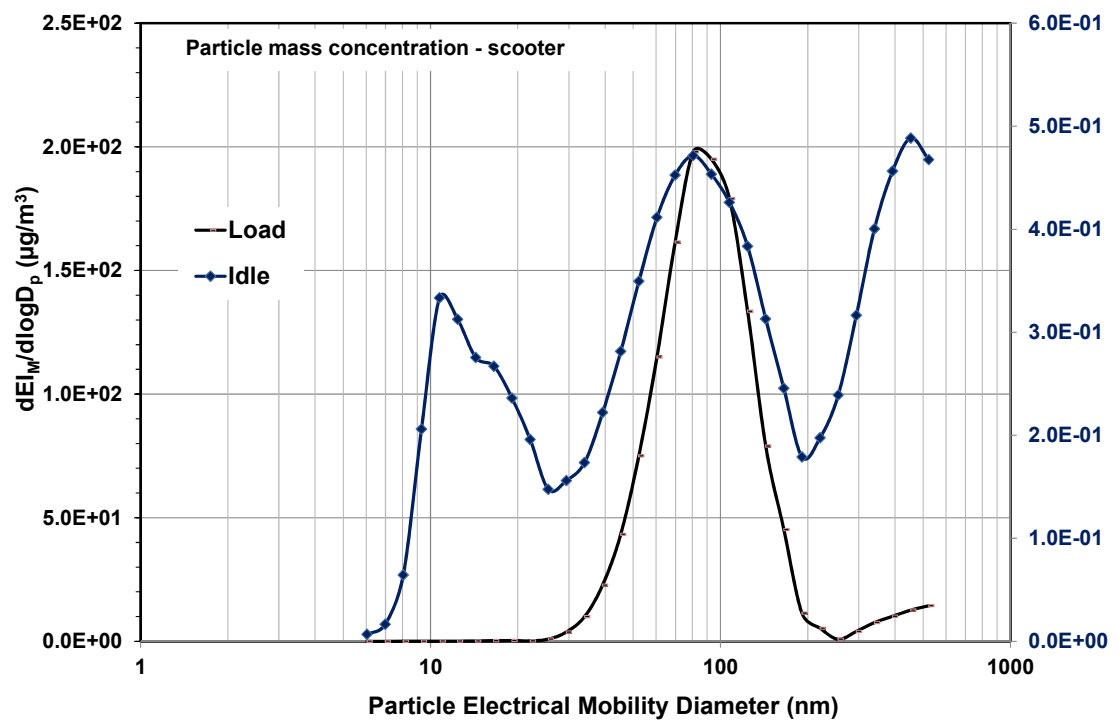

Figure 5. Particle mass distribution obtained for scooter.

Figure 6 shows the volume distribution of particles. When the engine is idling, the majority of the emitted volume of particles correspond to particles with a diameter of about $10 \mathrm{~nm}$, the number of which is the largest. Particles with diameters of 30-200 nm also have a significant share in the emitted volume. In the case of engine operation under load, it was found that particles with diameters of $30-200 \mathrm{~nm}$ are responsible for the vast majority of the generated volume of particles.

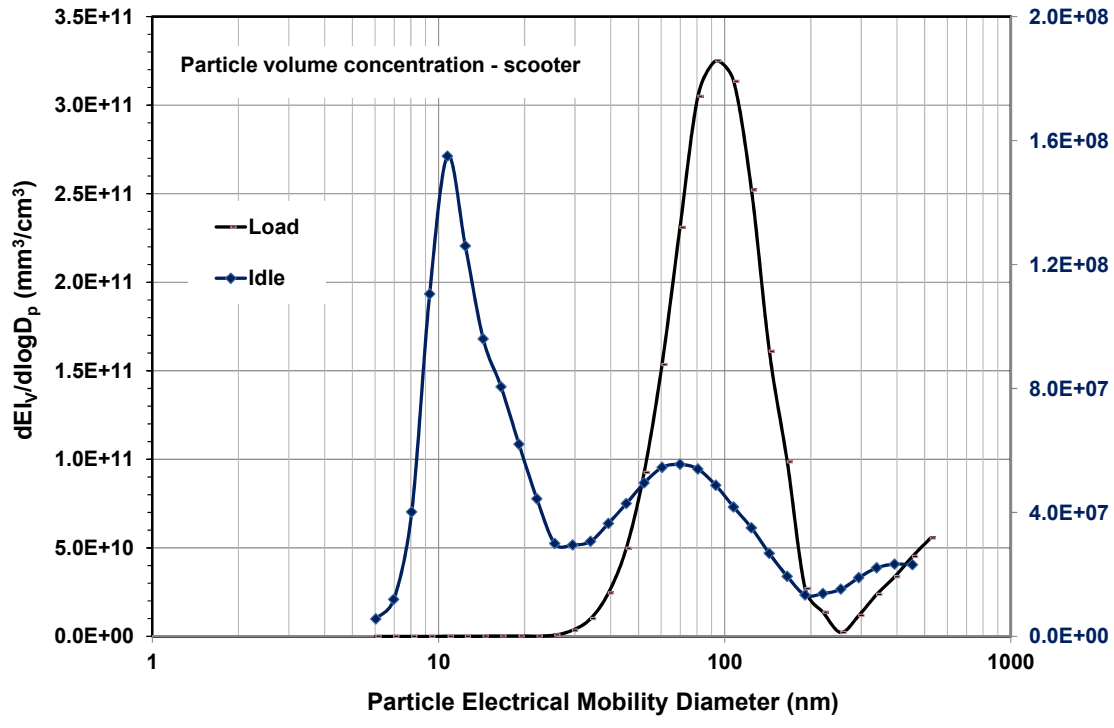

Figure 6. Particle volume distribution obtained for scooter.

\subsection{FTIR ATR of PM Adsorbed on Filter}

ATR spectra of PM adsorbed on the filter are presented in Figure 7.

All adsorbed PMs collected from both engines (Diesel and petrol) possess carbon black: a baseline sloping down to the right (\%T display) as carbon black displays absorption over the entire region from 4000 to $400 \mathrm{~cm}^{-1}$, and, when using the ATR technique, the effect of carbon black becomes greater, with deeper light penetration at the long wavelength (low wavenumber) end. The largest amount of carbon black is present at PMs emitted from Diesel engine, both working with and without load and during cold start. Slightly less carbon black is emitted in the case of an engine without load than with load. There 
are no evidence signals from alkanes or aromatic compounds; however, the weak signals at $\sim 2900 \mathrm{~cm}^{-1}$ at the range $1650-1400 \mathrm{~cm}^{-1}$ might be seen. It is larger for PM from the Diesel engine than petrol engine. The signals at $\sim 2300 \mathrm{~cm}^{-1}$ and $\sim 2100 \mathrm{~cm}^{-1}$ can be from nitryl compounds or alkanes, and they are stronger in the case of PMs from the Diesel engine than petrol engine. During the cold start of engine, more carbon black is emitted that is stronger for the Diesel engine than petrol engine. To summarize, the PMs from different engines, and working under the different conditions, emitted PMs that differ in the chemical composition.

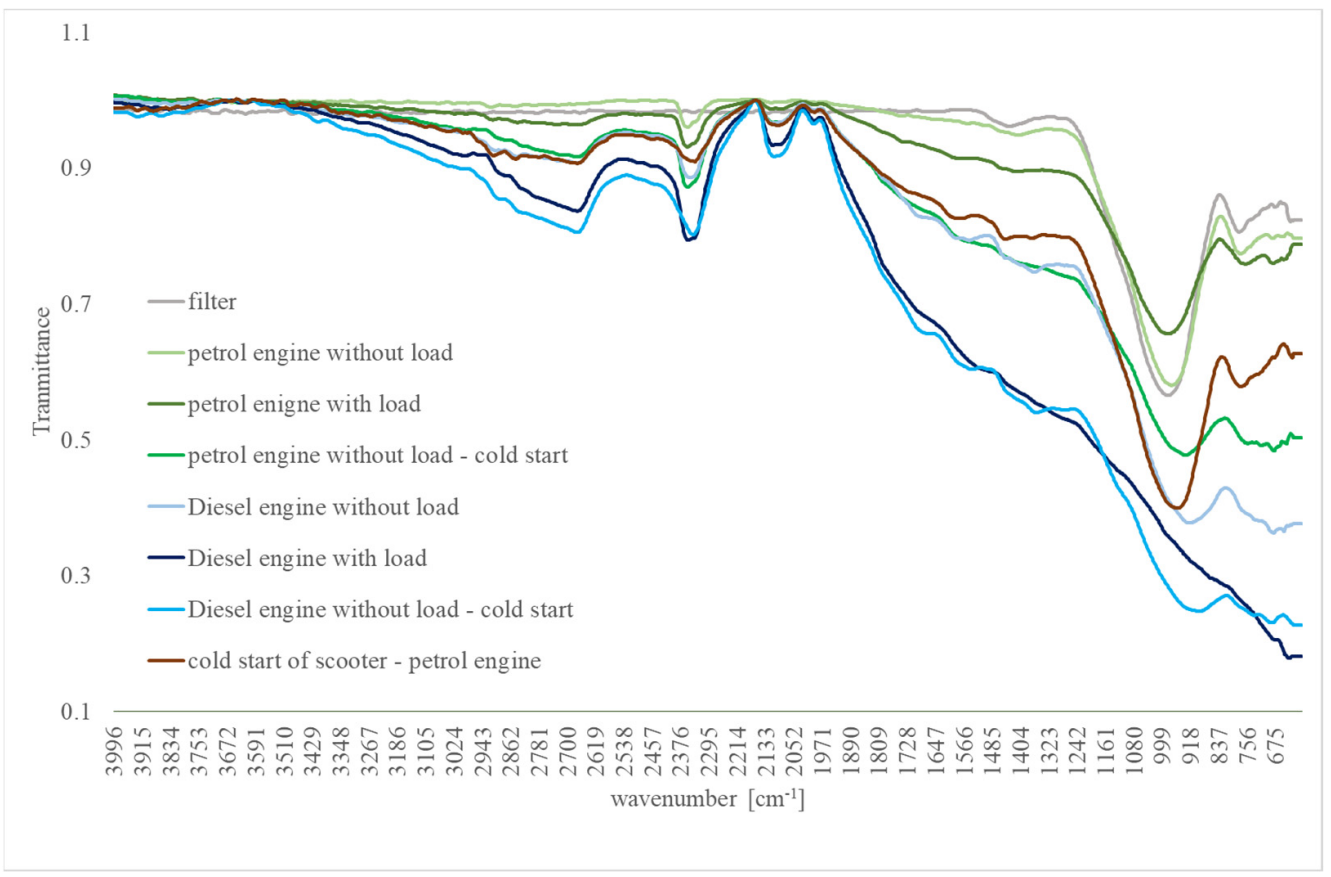

Figure 7. FTIR ATR spectra of PM adsorbed on filter from Diesel and petrol engine.

FTIR technique showed similarity and difference of the PM chemistry coming from the different engines and during their different work; however, this does not give an exact answer about the chemical composition of PM. More detailed and sophisticated methods must be applied. For this reason, in this study, the EGA technique was used. The aforementioned techniques were used in this research to investigate the thermal behavior of the filters and, at the same time, to examine the gasses released during thermal treatment. As a reference sample, the pure filter was investigated, and the results are shown in Figure 8.

\subsection{Evolved Gas Analysis (EGA)}

It can be seen in Figure 8a that decomposition of the pure filter is gradual with the total weight loss of approximately $10 \mathrm{wt} . \%$. Analysis of released gasses during decomposition showed presence of $\mathrm{CO}_{2} \mathrm{~m} / z=44$ and moisture $m / z=18$ (Figure $8 \mathbf{b}$, Table 2), where the first signal was present from approximately 200 to $600{ }^{\circ} \mathrm{C}$, and second one from approximately 200 to $900{ }^{\circ} \mathrm{C}$, respectively.

The results for petrol engine are shown in Figure 9. From the room temperature up to approximately $600{ }^{\circ} \mathrm{C}$, exothermic combustion of the filter is visible (Figure 9a). This process is associated with $\sim 8 \mathrm{wt} . \%$ mass loss and release of some organic compound $/ \mathrm{s}$ $\left(\mathrm{C}_{2} \mathrm{H}_{2} \mathrm{~S}\right.$ or $\mathrm{C}_{2} \mathrm{H}_{5} \mathrm{CHNH}_{2}(m / z=58)$ and water (Table 2$\left.)\right)$. 


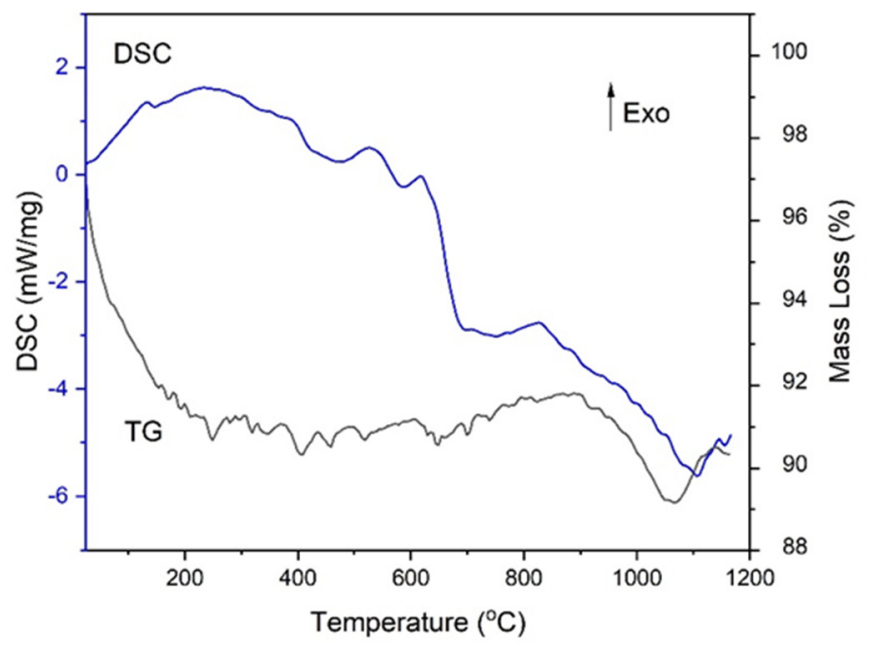

(a)

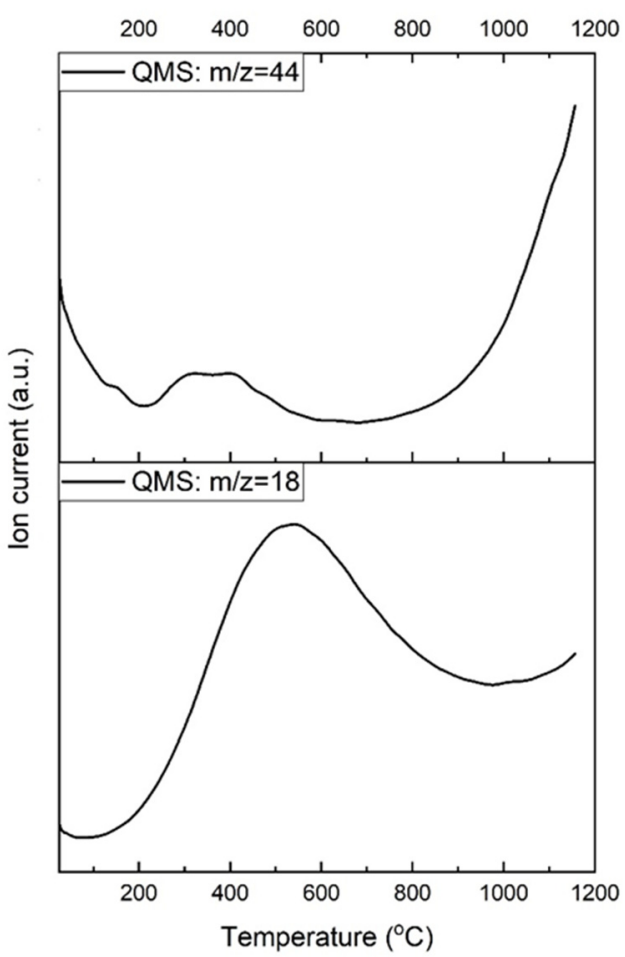

(b)

Figure 8. EGA results for the pure filter, where: (a) presents DSC-TG signals, and (b) shows QMS registered signals.

Table 2. Volatile ions released from filters identified by QMS during thermal analysis process.

\begin{tabular}{cccc}
\hline $\begin{array}{c}\text { Registered Mass } \\
(\mathrm{m} / \mathrm{z})\end{array}$ & Chemical Formula & $\begin{array}{r}\text { Registered Mass } \\
(\mathrm{m} / \mathrm{z})\end{array}$ & Chemical Formula \\
\hline 18 & $\mathrm{H}_{2} \mathrm{O}$ & 45 & $\begin{array}{c}\mathrm{CH}_{3} \mathrm{CHOH}, \\
\mathrm{CH}_{2} \mathrm{OCH}_{3}, \\
\mathrm{CH}_{2} \mathrm{CH}_{2} \mathrm{OH}, \mathrm{COOH}\end{array}$ \\
\hline 22 & $\begin{array}{c}\text { doubly charged } \\
\text { molecular ion, } \mathrm{CO}_{2}{ }^{2+}\end{array}$ & 46 & $\mathrm{NO}_{2}$ \\
\hline 43 & $\mathrm{C}_{3} \mathrm{H}_{7}, \mathrm{CH}_{3} \mathrm{C}=\mathrm{O}$ & 58 & $\mathrm{C}_{2} \mathrm{H}_{2} \mathrm{~S}$ \\
\hline 44 & $\mathrm{CO}_{2}, \mathrm{CH}_{3} \mathrm{CH}-\mathrm{CH}_{2}$ & & \\
\hline
\end{tabular}

On the other hand, the examination of the filter from the Diesel engine shows similar behavior (Figure 10), but different gasses emitted were registered. From the room temperature up to approximately $600{ }^{\circ} \mathrm{C}$, strong exothermic event on the DSC curve is visible, followed by less intense exothermic peek in the range from 600 to $700{ }^{\circ} \mathrm{C}$. In this temperature range, the biggest weight loss of the sample was registered ( 11 wt.\%). This weight loss very likely is observed due to emission and decomposition of organic compounds collected on the filter. There is also some moisture contribution, as well (Table 2).

\subsection{Scanning Electron Microscope with Energy Dispersive Spectroscopy (SEM-EDS)}

More in-depth information was obtained using SEM-EDS that makes it possible to study the elementary analysis of the PM. Figure 11 shows morphology of the PM for diesel end petrol engines. It can be seen that particles deposited on the Diesel engine fibers are smaller, and their amount is lower (Figure 11a,b) than in case of petrol engine (Figure 11c,d). PM from the petrol engine showed more agglomerations. SEM observations in AsB mode 
showed different weight of the collected contaminations (heavier particles shines). EDS analysis described below reveals that shining objects are iron particles.

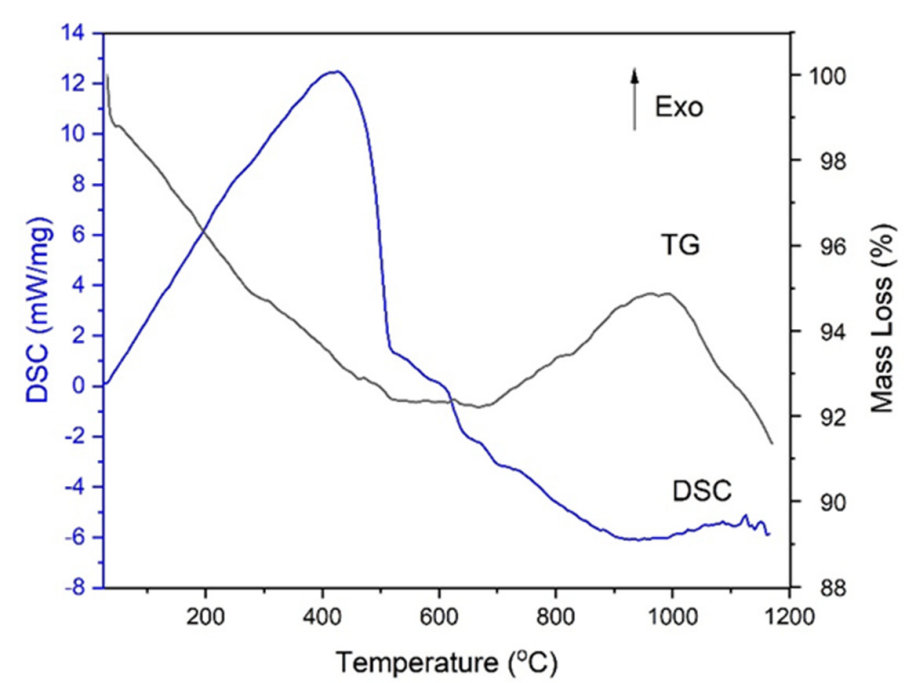

(a)

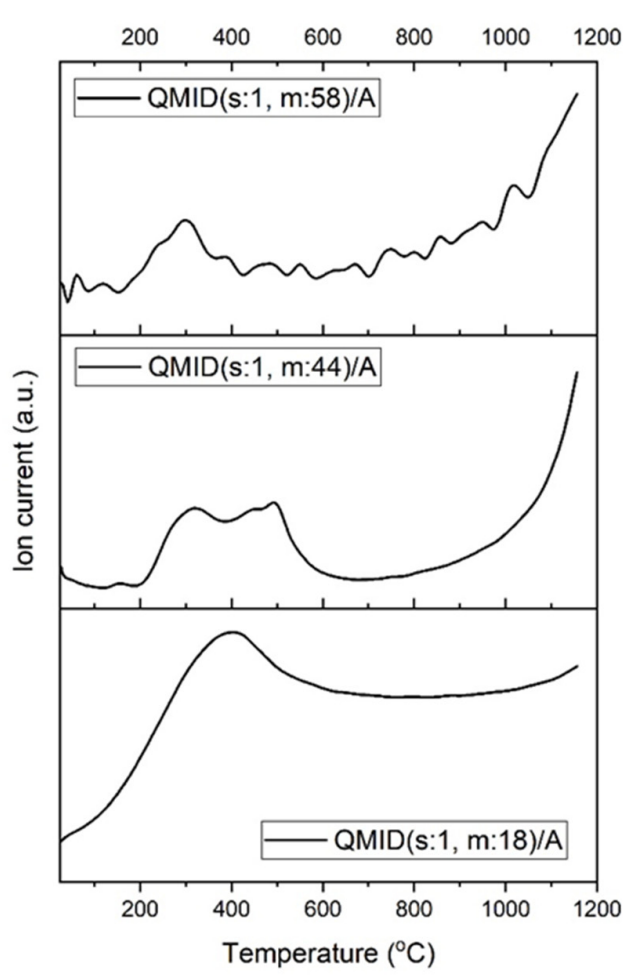

(b)

Figure 9. EGA results for petrol engine, where (a) presents DSC-TG signals, and (b) shows QMS registered signals.

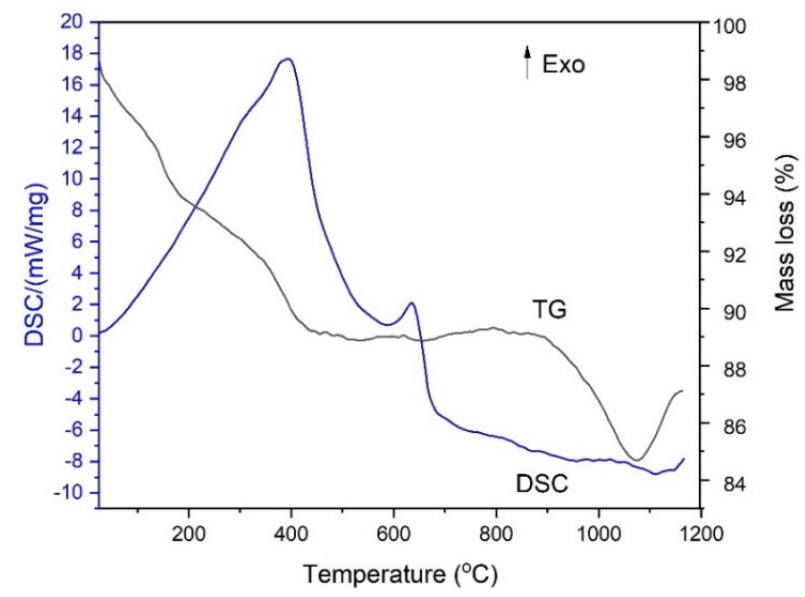

(a)

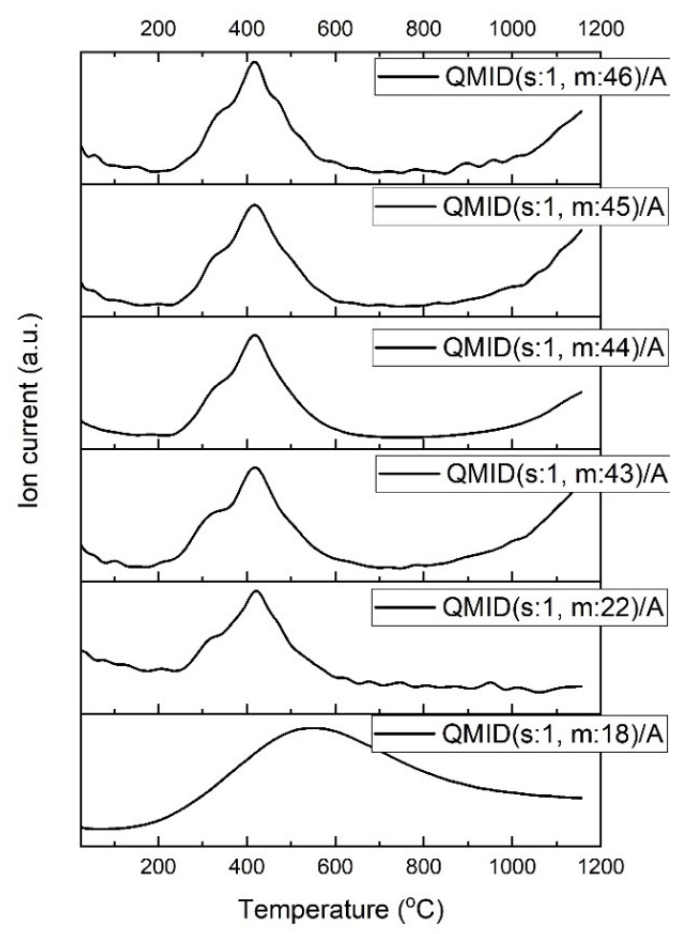

(b)

Figure 10. EGA results for Diesel engine, where (a) presents DSC-TG signals, and (b) shows QMS registered signals. 


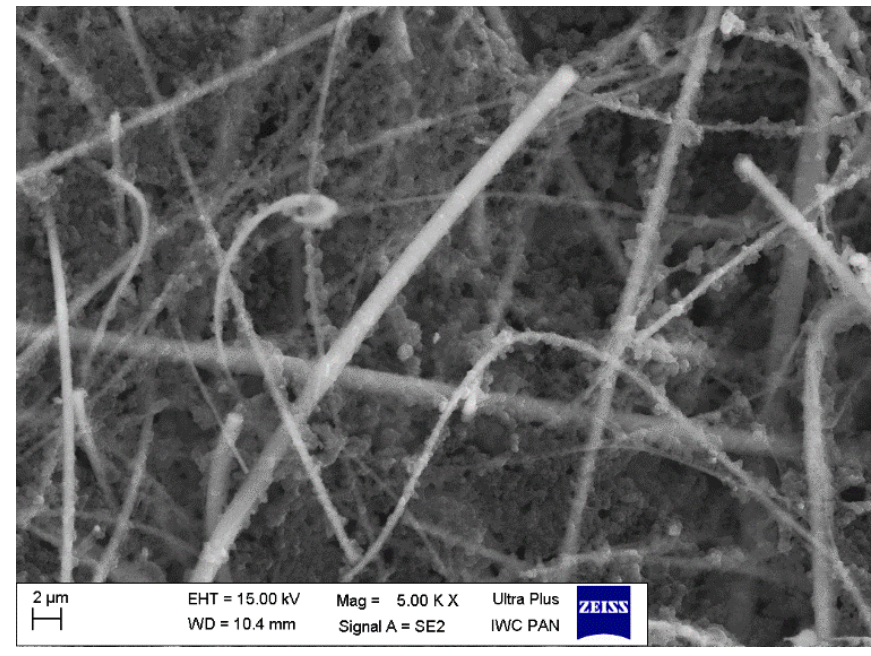

(a)

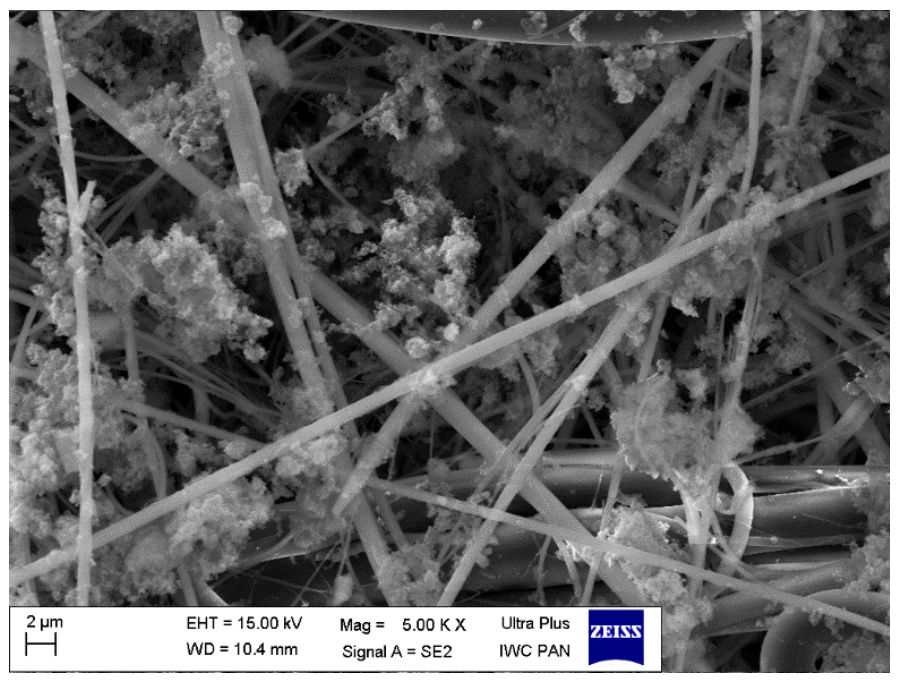

(c)

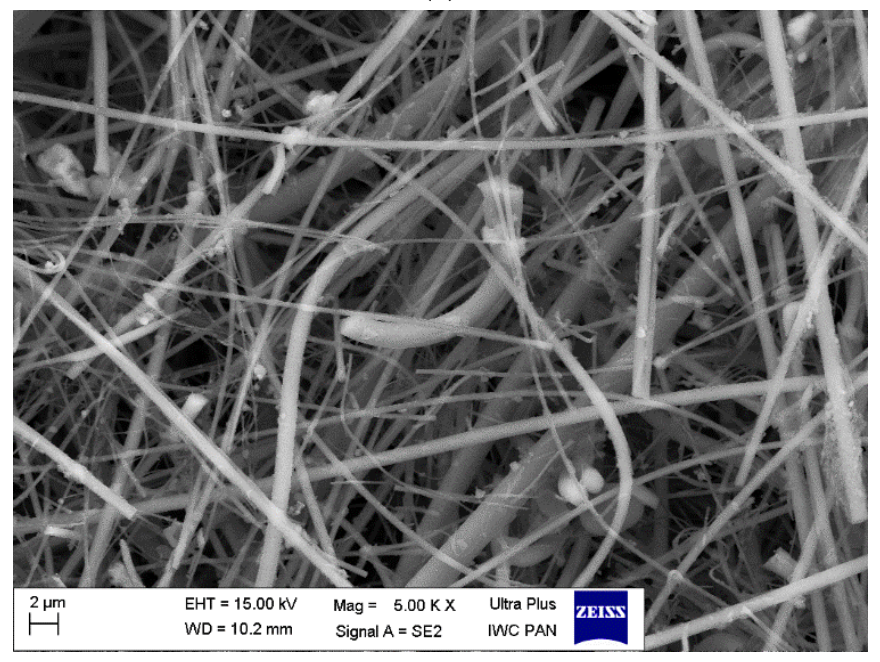

(e)

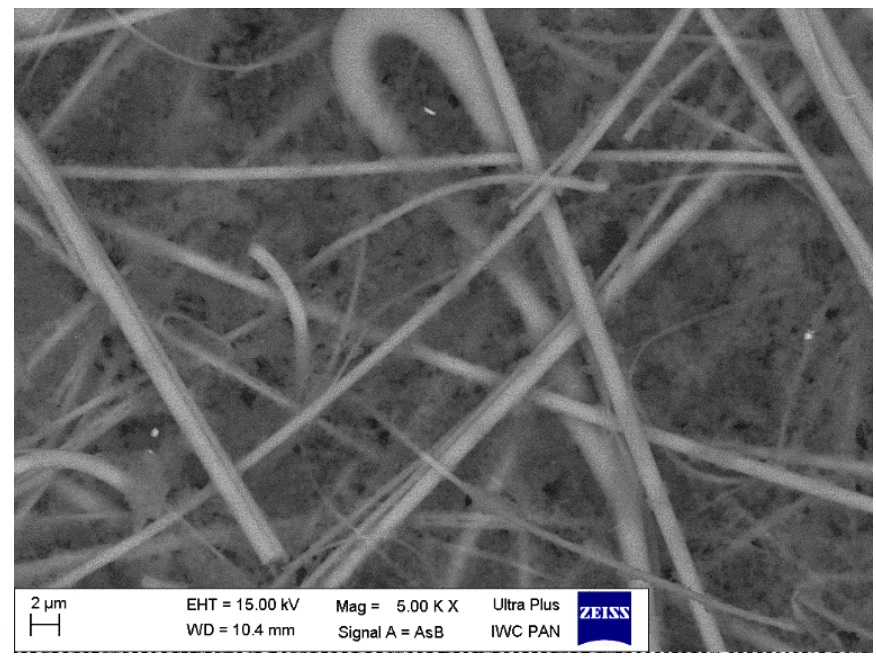

(b)

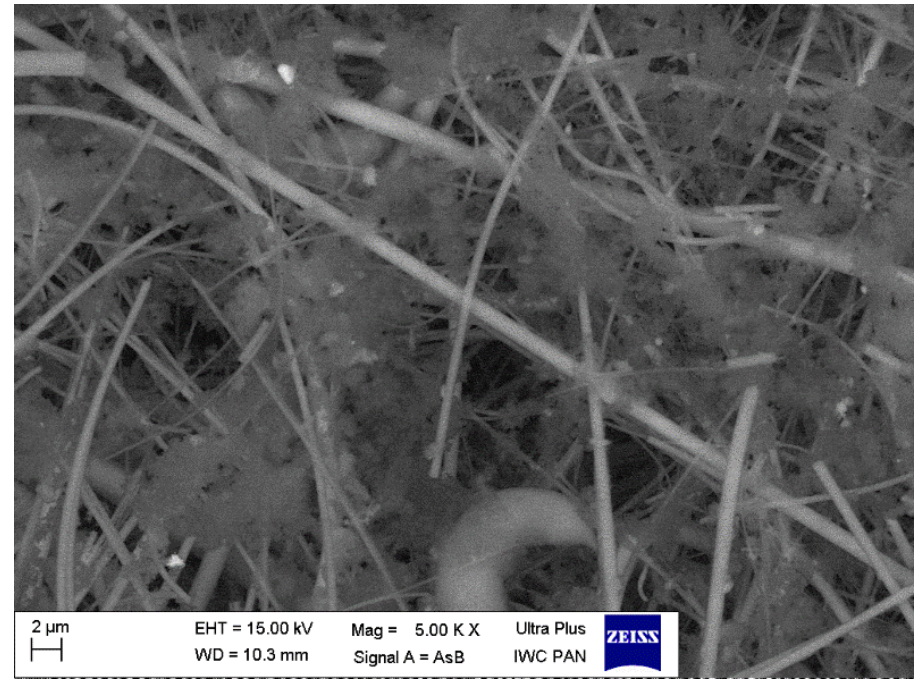

(d)

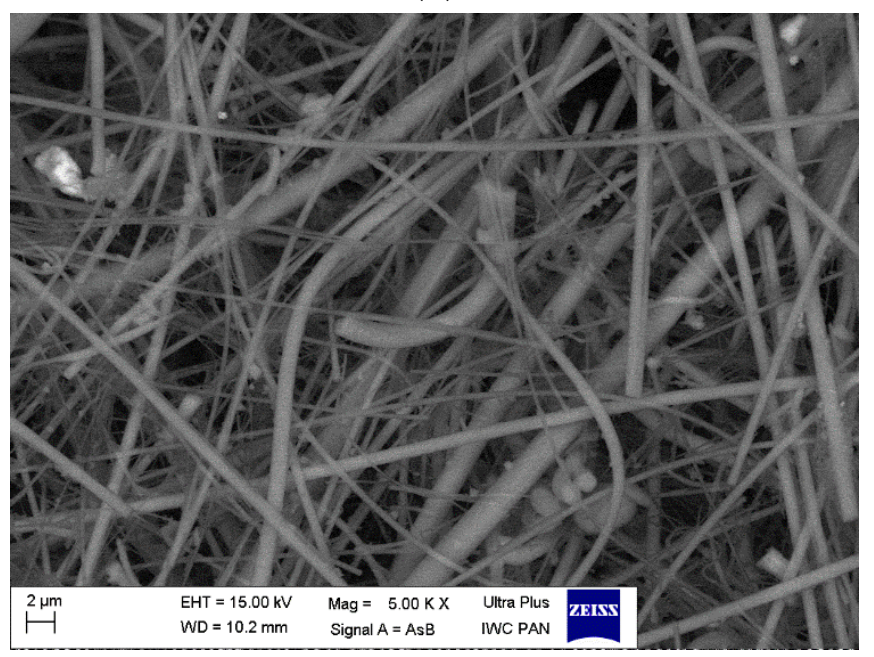

$(\mathbf{f})$

Figure 11. SEM images for Diesel engine in SE2 mode (a), and AsB mode (b); petrol engine (scooter) in SE2 mode (c), and AsB mode (d); pure filter in SE2 mode (e) and AsB mode (f). 
The example of EDS area chosen from SEM micrographs for the Diesel and petrol (scooter) engine is shown in Figure 12.

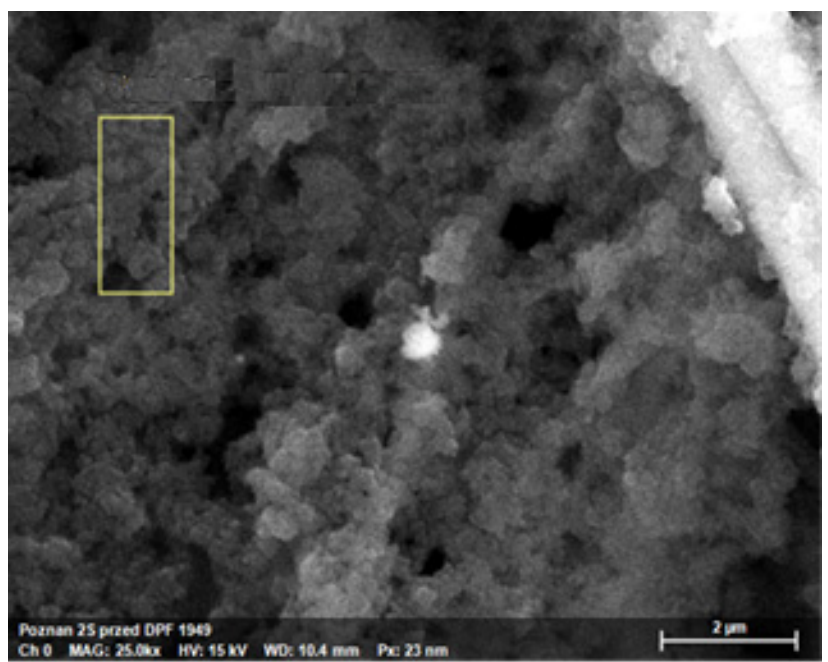

(a)

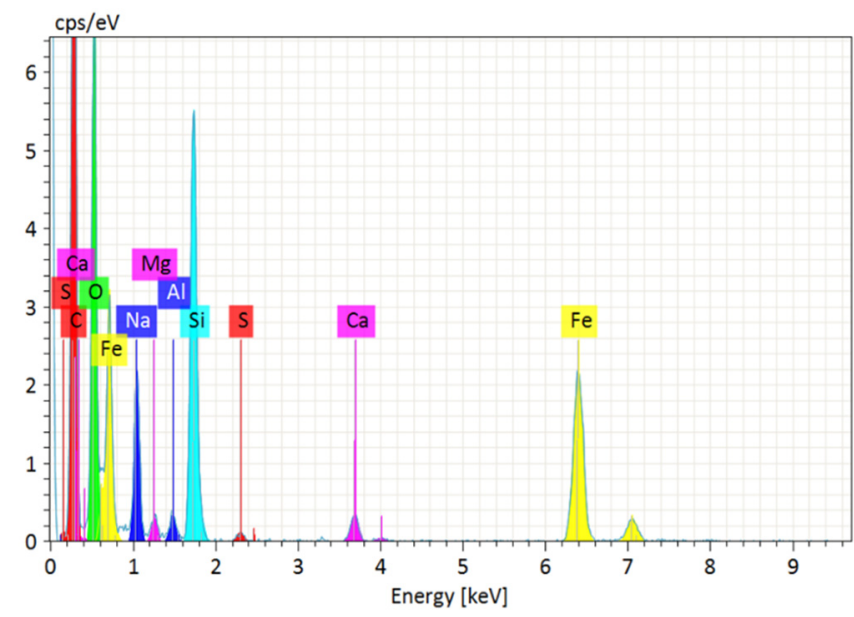

(c)

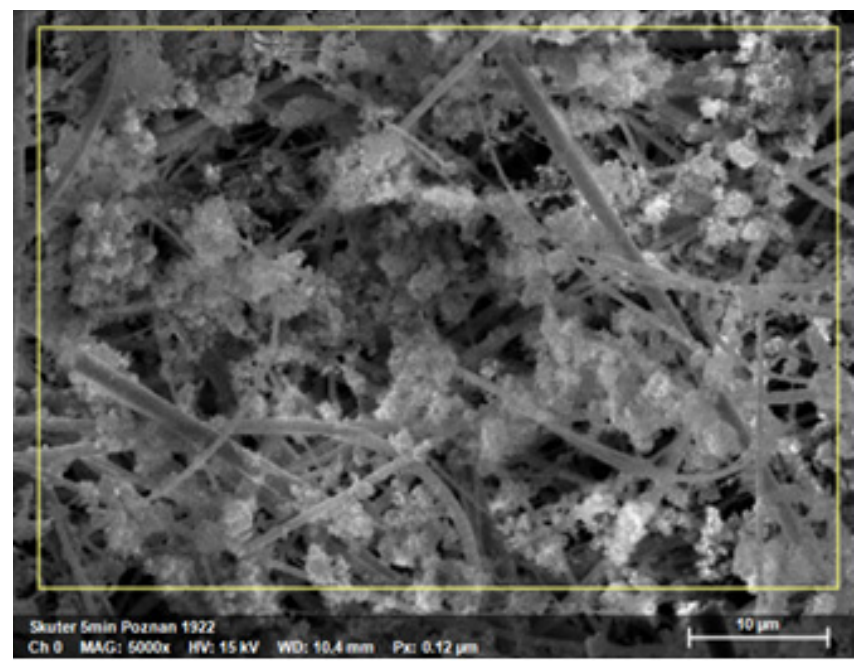

(b)

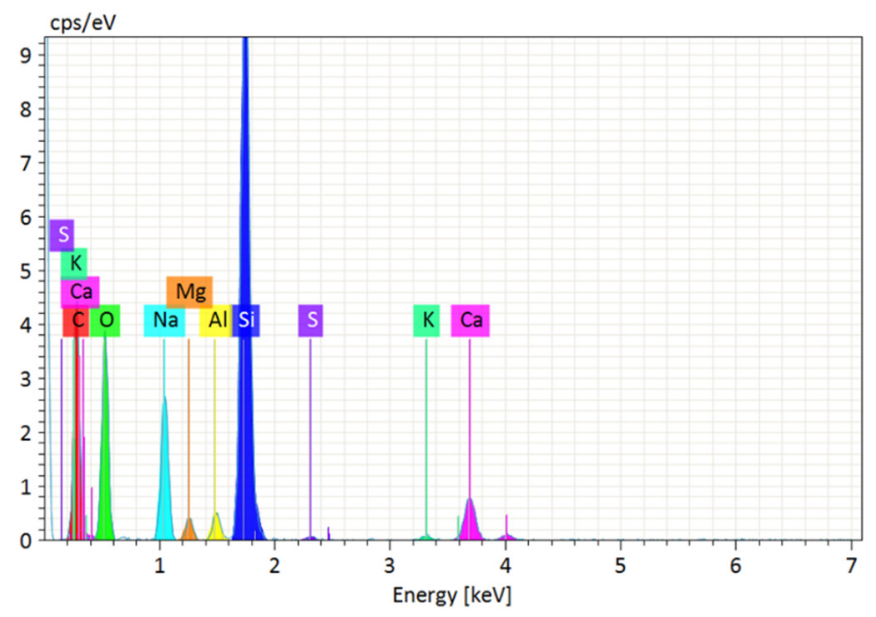

(d)

Figure 12. SEM micrographs for (a) Diesel engine and (b) petrol engine (scooter), showing area of EDS analysis. Elemental analysis for (c) Diesel and (d) scooter.

SEM-EDS analysis enabled to quantitatively assess the elemental analysis of PMs from the Diesel and petrol engine (Table 3). EDS analysis indicates that the main component of PMs from both engines is carbon (most probably from organic compounds originated from combustion process). The small amount on the pure filter is the effect of covering the filter by very thin layer of carbon $(6 \mathrm{~nm})$ before SEM-EDS imaging. The amount of oxygen is similar to the pure filter in the case of the Diesel engine, and it is significantly smaller for the petrol engine: this phenomenon can be the effect of covering filter fibers by carbon agglomerates in the case of the petrol engine and more distracted particles in the case of Diesel engine that do not stick the filter fibers. This phenomenon is also present in the case of $\mathrm{Na}, \mathrm{Ca}, \mathrm{Si}, \mathrm{Al}$, and $\mathrm{Mg}$. Surprisingly, sulfur is present in the case of PMs from both engines, on a similar level that can come from some engine parts/oils. Only for PMs for Diesel engine was Fe noticed. 
Table 3. Elemental Analysis of filters from Diesel and petrol engines.

\begin{tabular}{|c|c|c|c|c|c|c|}
\hline \multicolumn{3}{|c|}{ Elemental Composition for Diesel Engine } & \multicolumn{2}{|c|}{$\begin{array}{c}\text { Elemental Composition for } \\
\text { Petrol Engine }\end{array}$} & \multicolumn{2}{|c|}{$\begin{array}{c}\text { Elemental Composition for } \\
\text { Pure Filter }\end{array}$} \\
\hline Element & Mass Norm. (\%) & $\begin{array}{l}\text { Abs. Error } \\
\text { (1sigma) \% }\end{array}$ & Mass Norm. (\%) & $\begin{array}{l}\text { Abs. Error } \\
\text { (1sigma) \% }\end{array}$ & Mass Norm. (\%) & $\begin{array}{l}\text { Abs.Error } \\
\text { (1sigma) \% }\end{array}$ \\
\hline Carbon & 45.72 & 8.98 & 41.69 & 7.12 & 9.28 & 1.75 \\
\hline Oxygen & 38.48 & 5.19 & 28.95 & 4.96 & 43.75 & 5.09 \\
\hline Sodium & 3.65 & 0.39 & 5.83 & 0.48 & 7.46 & 5.09 \\
\hline Silicon & 6.16 & 0.44 & 18.63 & 0.98 & 26.11 & 1.03 \\
\hline Calcium & 0.84 & 0.09 & 2.86 & 0.15 & 1.43 & 0.09 \\
\hline Iron & 18.02 & 0.91 & Not detected & Not detected & Not detected & Not detected \\
\hline Sulfur & 0.16 & 0.05 & 0.15 & 0.05 & Not detected & Not detected \\
\hline Aluminum & 0.38 & 0.07 & 0.90 & 0.09 & 2.88 & 0.16 \\
\hline Magnesium & 0.38 & 0.08 & 0.77 & 0.09 & Not detected & Not detected \\
\hline Potassium & Not detected & Not detected & 0.22 & 0.05 & 2.43 & 0.11 \\
\hline
\end{tabular}

To compare these results with other available studies, it can be seen that, in research of Güney and Aladag [39], where gasoline-fueled vehicles were tested in terms of chemical analysis of particulate matter; in particular, SEM analyses show that PM is formed by solidification and agglomeration [39]. In this publication, the SEM analysis also showed that PM from gasoline engines shows more agglomerations, which was mentioned in point 3.6. In research of Güney and Aladag, the EDS analysis allowed for indicating 20 elements of PM: C, F, N, Na, O, Mg, Br, Si, Hg, S, P, Pb, Ca, Cr, Mn, Fe, Ni, Co, Cu, and Zn [39]. Some of the elements were also detected in SEM-EDS analysis in this paper, which is shown in Figure 12 and Table 3. Yang et al. [40] investigated the chemical composition of fine particulate matter emitted by gasoline and diesel vehicles, and this research showed that the most dominant components of PM2,5 for the Diesel and gasoline vehicle were carbonaceous species [40]. Research of Yang et al. also investigated that the top five metal elements in PM2,5 were $\mathrm{Na}, \mathrm{Ca}, \mathrm{Fe}, \mathrm{Zn}$, and $\mathrm{Al}$, which also can be confirmed by studies of Cheung et al. [41] and Hao et al. [42].

\section{Conclusions}

The article presents the results of the analysis of the physical properties and chemical composition of particles emitted by a diesel and gasoline engine. The research focused not only on data obtained from particulate matter analyzer but also related to the chemical analysis of particulate matter from the tested engines, which allowed for comparing chemical composition and properties of particles emitted from diesel engine and petrol engine. There were three chemical analyses: Fourier Transform Infrared Spectroscopy, Scanning Electron Microscope with Energy Dispersive Spectroscopy, and Evolution Gas Analysis, which is a very extended analysis compared to the available studies. The diesel engine was mounted on an engine dynamometer; therefore, it was possible to analyze it in depth. In the case of the petrol engine, it was mounted on a scooter; therefore, a chassis dynamometer was used. The diesel engine emitted particles in the range of 50-120 nm. With the increase in the engine load, the specific emission of particulate matter increased. Increasing the load also resulted in an increase in the specific emission of the number and mass (particles per kilogram of fuel burnt). Additionally, the tests included the results before and after regeneration of the diesel particulate filter. In the case of a gasoline engine running without load, the emission of particles smaller than $30 \mathrm{~nm}$ was mainly observed. Increasing load of the gasoline engine resulted in an increase in both the concentration of particles and their diameter (average diameter to $90 \mathrm{~nm}$ ).

Particles emitted from the Diesel and petrol engine differ in the size, number, and the chemical composition. PMs emitted from the Diesel engine are smaller, and more carbon black is emitted than in the case of petrol engine. It is a huge challenge to study the exact composition of PMs collected on the filters. Very accurate techniques were used in this 
paper, and it is possible to estimate the PMs chemical composition. EGA, SEM-EDS, and FTIR results show the differences of PMs chemical composition emitted from the Diesel and petrol engine. It can be concluded that PMs emitted from petrol engine agglomerate. The chemical composition is similar; however, for the Diesel engine, more carbon black is emitted. In case of both engines, sulfur compounds are observed.

On the basis of the conducted experimental studies, the following conclusions can be presented:

1. All adsorbed particulate matter collected from the Diesel and petrol engine contain carbon black. Carbon black shows absorption in the entire area from 4000 to $400 \mathrm{~cm}^{-1}$, and, when using the ATR technique, the effect of carbon black becomes greater with deeper light penetration at the long wavelength end.

2. The largest amount of carbon black is present at particulate matter emitted from the Diesel engine, both working with and without load and during cold start. Slightly less carbon black is emitted in the case of an engine without load than with load.

3. There are no evidence signals from alkanes or aromatic compounds; however, the weak signals at $2900 \mathrm{~cm}^{-1}$ at the range $1650-1400 \mathrm{~cm}^{-1}$ might be seen. It is larger for PM from the Diesel engine than the petrol engine.

4. It can be seen that particles deposited on the Diesel engine fibers are smaller, and their amount is lower, than in case of petrol engine. PM from the petrol engine show more agglomerations.

5. The main component of PM from both engines is carbon, which most likely comes from organic compounds derived from the combustion process.

6. The amount of oxygen is similar to the pure filter in the case of the Diesel engine, and it is significantly smaller for the petrol engine: this phenomenon can be the effect of covering filter fibers by carbon agglomerates in the case of the petrol engine and more distracted particles in the case of Diesel engine that do not stick the filter fibers. This phenomenon is also present in case of $\mathrm{Na}, \mathrm{Ca}, \mathrm{Si}, \mathrm{Al}$, and $\mathrm{Mg}$.

7. Sulfur is present in particulate matter from both engines on the similar level.

8. Fe was noticed only for particulate matters from the Diesel engine.

Author Contributions: Conceptualization, R.J. and B.S.; methodology, R.J., B.S., I.K. and J.M.; software, R.J., B.S., I.K. and J.M.; validation, R.J. and B.S., formal analysis, R.J.; investigation, B.S.; resources, R.J.; data curation, R.J., B.S., I.K., J.M. and P.K.; writing-original draft preparation, R.J., B.S., I.K., J.M. and P.K., writing-review and editing, R.J.; visualization, B.S., I.K. and J.M.; supervision, R.J.; project administration, R.J.; funding acquisition, R.J. All authors have read and agreed to the published version of the manuscript.

Funding: The research subject was carried out with the use of equipment funded by the project CePT, reference: POIG.02.02.00-14-024/08, financed by the European Regional Development Fund within the Operational Programme “Innovative Economy" for 2007-2013.

Institutional Review Board Statement: Not applicable.

Informed Consent Statement: Not applicable.

Conflicts of Interest: The authors declare no conflict of interest.

\section{References}

1. Sicard, P.; Agathokleous, E.; De Marco, A.; Paoletti, E.; Calatayud, V. Urban population exposure to air pollution in Europe over the last decades. Environ. Sci. Eur. 2021, 33, 1-12. [CrossRef] [PubMed]

2. Lelieveld, J.; Evans, J.S.; Fnais, M.; Giannadaki, D.; Pozzer, A. The contribution of outdoor air pollution sources to premature mortality on a global scale. Nature 2015, 525, 367-371. [CrossRef] [PubMed]

3. OECD/European Union. Health at a Glance: Europe 2020: State of Health in the EU Cycle; OECD Publishing: Paris, France, 2020. [CrossRef]

4. World Health Organization. Air Pollution. Available online: https://www.who.int/health-topics/air-pollution\#tab=tab_2 (accessed on 3 January 2021).

5. WHO. Air Quality Guidelines for Particulate Matter, Ozone, Nitrogen Dioxide and Sulfur Dioxide; WHO: Geneva, Switzerland, 2006.

6. Available online: https:/ / whoairquality.shinyapps.io/AirQualityStandards / (accessed on 29 June 2021). 
7. Brook, R.D.; Rajagopalan, S.; Pope, C.A.; Brook, J.R.; Bhatnagar, A.; Diez-Roux, A.V.; Holguin, F.; Hong, Y.; Luepker, R.V.; Mittleman, M.A.; et al. Particulate Matter Air Pollution and Cardiovascular Disease: An update to the scientific statement from the american heart association. Circulation 2010, 121, 2331-2378. [CrossRef]

8. Jasiński, R.; Galant-Gołębiewska, M.; Nowak, M.; Ginter, M.; Kurzawska, P.; Kurtyka, K.; Maciejewska, M. Case Study of Pollution with Particulate Matter in Selected Locations of Polish Cities. Energies 2021, 14, 2529. [CrossRef]

9. Schikowski, T.; Vossoughi, M.; Vierkötter, A.; Schulte, T.; Teichert, T.; Sugiri, D.; Fehsel, K.; Tzivian, L.; Bae, I.-S.; Ranft, U.; et al. Association of air pollution with cognitive functions and its modification by APOE gene variants in elderly women. Environ. Res. 2015, 142, 10-16. [CrossRef]

10. Tonne, C.; Elbaz, A.; Beevers, S.; Singh-Manoux, A. Traffic-related Air Pollution in Relation to Cognitive Function in Older Adults. Epidemiology 2014, 25, 674-681. [CrossRef] [PubMed]

11. Ailshire, J.A.; Crimmins, E.M. Fine Particulate Matter Air Pollution and Cognitive Function Among Older US Adults. Am. J. Epidemiol. 2014, 180, 359-366. [CrossRef] [PubMed]

12. Gao, H.; Shi, J.; Cheng, H.; Zhang, Y. The impact of long- and short-term exposure to different ambient air pollutants on cognitive function in China. Environ. Int. 2021, 151, 106416. [CrossRef]

13. Pielecha, J.; Merkisz, J.; Markowski, J.; Jasiński, R. Analysis of Passenger Car Emission Factors in RDE Tests. E3S Web Conf. 2016, 10, 73. [CrossRef]

14. Guevara, M. Emissions of Primary Particulate Matter. Issues Environ. Sci. Technol. 2016, 1-34. [CrossRef]

15. Reşitoğlu, İ.A.; Altinişik, K.; Keskin, A. The pollutant emissions from diesel-engine vehicles and exhaust aftertreatment systems. Clean Technol. Environ. Policy 2015, 17, 15-27. [CrossRef]

16. Report-Vehicles in Use, Europe 2019-ACEA-European Automobile Manufacturers' Association. 2021. Available online: https: //www.acea.auto/publication/report-vehicles-in-use-europe-2019/ (accessed on 17 August 2021).

17. Dun, C.; Horton, G.; Kollamthodi, S. Improvements to the Definition of Lifetime Mileage of Light Duty Vehicles; Ricardo-AEA: London, UK, 2015.

18. Burtscher, H. Physical characterization of particulate emissions from diesel engines: A review. J. Aerosol Sci. 2005, 36, 896-932. [CrossRef]

19. Keskinen, J.; Rönkkö, T. Can Real-World Diesel Exhaust Particle Size Distribution be Reproduced in the Laboratory? A Critical Review Jorma Keskinen. J. Air Waste Manag. Assoc. 2010, 60, 1245-1255. [CrossRef] [PubMed]

20. Wróblewski, P.; Iskra, A. Problems of Reducing Friction Losses of a Piston-Ring-Cylinder Configuration in a Combustion Piston Engine with an Increased Isochoric Pressure Gain; SAE Technical Paper Series, SAE Technical Paper 2020-01-2227; SAE International: Warrendale, PA, USA, 2020. [CrossRef]

21. R'Mili, B.; Boréave, A.; Meme, A.; Vernoux, P.; Leblanc, M.; Noël, L.; Raux, S.; D'Anna, B. Physico-Chemical Characterization of Fine and Ultrafine Particles Emitted during Diesel Particulate Filter Active Regeneration of Euro5 Diesel Vehicles. Environ. Sci. Technol. 2018, 52, 3312-3319. [CrossRef]

22. Staps, I.; Ligterink, N. Diesel Particle Filters; TNO: The Hague, The Netherlands, 2018. [CrossRef]

23. Steininger, N. Particle number emission limits for Euro 6 positive ignition vehicles (PI). In Proceedings of the 15 ETH Conference on Combustion Generated Nano-Particles, Zurich, Switzerland, 27-29 June 2011.

24. Diesel Particulate Filters-GOV.UK. Retrieved 17 August 2021. Available online: https://www.gov.uk/government/publications/ diesel-particulate-filters-guidance-note/diesel-particulate-filters (accessed on 17 August 2021).

25. Green-Zones.eu.-Green-Zones.eu. Retrieved 17 August 2021. Available online: https:/ /www.green-zones.eu/en/ (accessed on 17 August 2021).

26. Plötz, P.; Axsen, J.; Funke, S.A.; Gnann, T. Designing car bans for sustainable transportation. Nat. Sustain. 2019, 2, 534-536. [CrossRef]

27. Chang, A.S.F.; Kalawsky, R.S. European transport sector interventions for smart city. In Proceedings of the 2017 7th International Conference on Power Electronics Systems and Applications-Smart Mobility, Power Transfer \& Security (PESA), Hong Kong, China, 12-14 December 2017; IEEE: New York, NY, USA, 2017; Volume 5, pp. 1-6. [CrossRef]

28. National Research Council. Cost, Effectiveness, and Deployment of Fuel Economy Technologies for Light-Duty Vehicles; National Academies Press: Cambridge, MA, USA, 2015.

29. Conway, G.; Joshi, A.; Leach, F.; García, A.; Senecal, P.K. A review of current and future powertrain technologies and trends in 2020. Transp. Eng. 2021, 5, 100080. [CrossRef]

30. Macioszek, E.; Sierpiński, G. Charging Stations for Electric Vehicles-Current Situation in Poland. Commun. Comput. Inf. Sci. 2020, 13, 124-137. [CrossRef]

31. Wróblewski, P.; Drożdż, W.; Lewicki, W.; Dowejko, J. Total Cost of Ownership and Its Potential Consequences for the Development of the Hydrogen Fuel Cell Powered Vehicle Market in Poland. Energies 2021, 14, 2131. [CrossRef]

32. Li, Q.; Zhu, Q.; Xu, M.; Zhao, Y.; Narayan, K.; Liu, Y. Estimating the Impact of COVID-19 on the PM 2.5 Levels in China with a Satellite-Driven Machine Learning Model. Remote Sens. 2021, 13, 1351. [CrossRef]

33. Rogula-Kozłowska, W.; Klejnowski, K.; Rogula-Kopiec, P.; Ośródka, L.; Krajny, E.; Błaszczak, B.; Mathews, B. Spatial and seasonal variability of the mass concentration and chemical composition of PM2.5 in Poland. Air Qual. Atmos. Health 2014, 7, 41-58. [CrossRef] 
34. Popovicheva, O.B.; Kireeva, E.D.; Shonija, N.K.; Vojtisek-Lom, M.; Schwarz, J. FTIR analysis of surface functionalities on particulate matter produced by off-road diesel engines operating on diesel and biofuel. Environ. Sci. Pollut. Res. 2014, 22, 4534-4544. [CrossRef]

35. Mico, S.; Tsaousi, E.; Deda, A.; Pomonis, P. Characterization of airborne particles and source identification using SEM/EDS. Eur. Chem. Bull. 2015, 4, 224-229. [CrossRef]

36. Genga, A.; Baglivi, F.; Siciliano, M.; Siciliano, T.; Aiello, D.; Tortorella, C. Chemical and Morphological Study of Particulate Matter Analysed by Sem-Eds. In Proceedings of the 4th Imeko TC19 Symposium on Environmental Instrumentation and Measurements Protecting Environment, Climate Changes and Pollution Control, Lecce, Italy, 3-4 June 2013; pp. 43-46.

37. Kurzawska, P.; Jasiński, R. Overview of Sustainable Aviation Fuels with Emission Characteristic and Particles Emission of the Turbine Engine Fueled ATJ Blends with Different Percentages of ATJ Fuel. Energies 2021, 14, 1858. [CrossRef]

38. Merkisz, J. On-road exhaust emission testing. Combust. Engines 2011, 146, 3-15. [CrossRef]

39. Güney, B.; Aladağ, A. Microstructural characterization of particulate matter from gasoline-fuelled vehicle emissions. J. Eng. Res. Rep. 2020, 16, 29-39. [CrossRef]

40. Yang, H.H.; Dhital, N.B.; Wang, L.C.; Hsieh, Y.S.; Lee, K.T.; Hsu, Y.T.; Huang, S.C. Chemical characterization of fine particulate matter in gasoline and diesel vehicle exhaust. Aerosol Air Qual. Res. 2019, 19, 1349-1449. [CrossRef]

41. Cheung, K.L.; Ntziachristos, L.; Tzamkiozis, T.; Schauer, J.J.; Samaras, Z.; Moore, K.F.; Sioutas, C. Emissions of particulate trace elements, metals and organic species from gasoline, diesel, and biodiesel passenger vehicles and their relation to oxidative potential. Aerosol Sci. Technol. 2010, 44, 500-513. [CrossRef]

42. Hao, Y.; Gao, C.; Deng, S.; Yuan, M.; Song, W.; Lu, Z.; Qiu, Z. Chemical characterisation of PM2.5 emitted from motor vehicles powered by diesel, gasoline, natural gas and methanol fuel. Sci. Total Environ. 2019, 674, 128-139. [CrossRef] [PubMed] 